Historic, Archive Document

Do not assume content reflects current scientific knowledge, policies, or practices. 



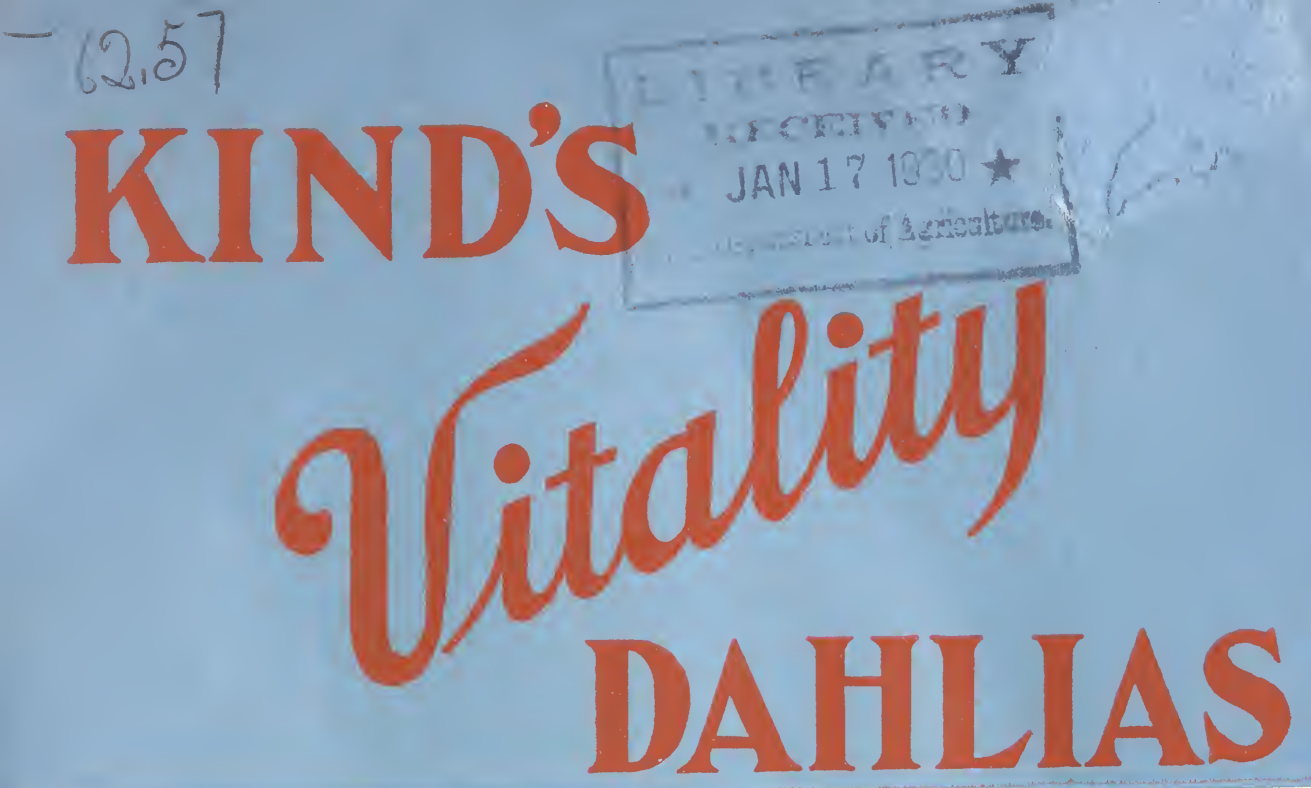

\section{SAY IT WITH FLOWERS}

From

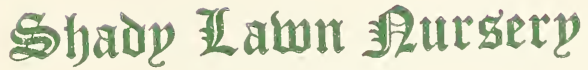
HUGO KIND HAMMONTON, N. J.
POSTMASTER

This Parcel contains Merchandise and is mailable as 4th Class Matter. It may be opened for postal inspection.

Return Postage Guaranteed.
2

\section{U. S. DePartment of Agriculture}

W ASHINGTON, D. C.

Bureau of Plant Industry Horticulture

GOVERNMENT PRINTING OFFICE

J32437

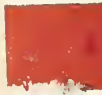




\section{ORDER SHEET}

\section{SHADY LAWN NURSERIES}

Hugo Kind

Date

State here whether you want shipment to

be made by Mail, Express or Freight

Name

Street Address or Box No.

Post Office

County

R. D. Route

State

If different from Post Office give?

name of Express or Freight Office

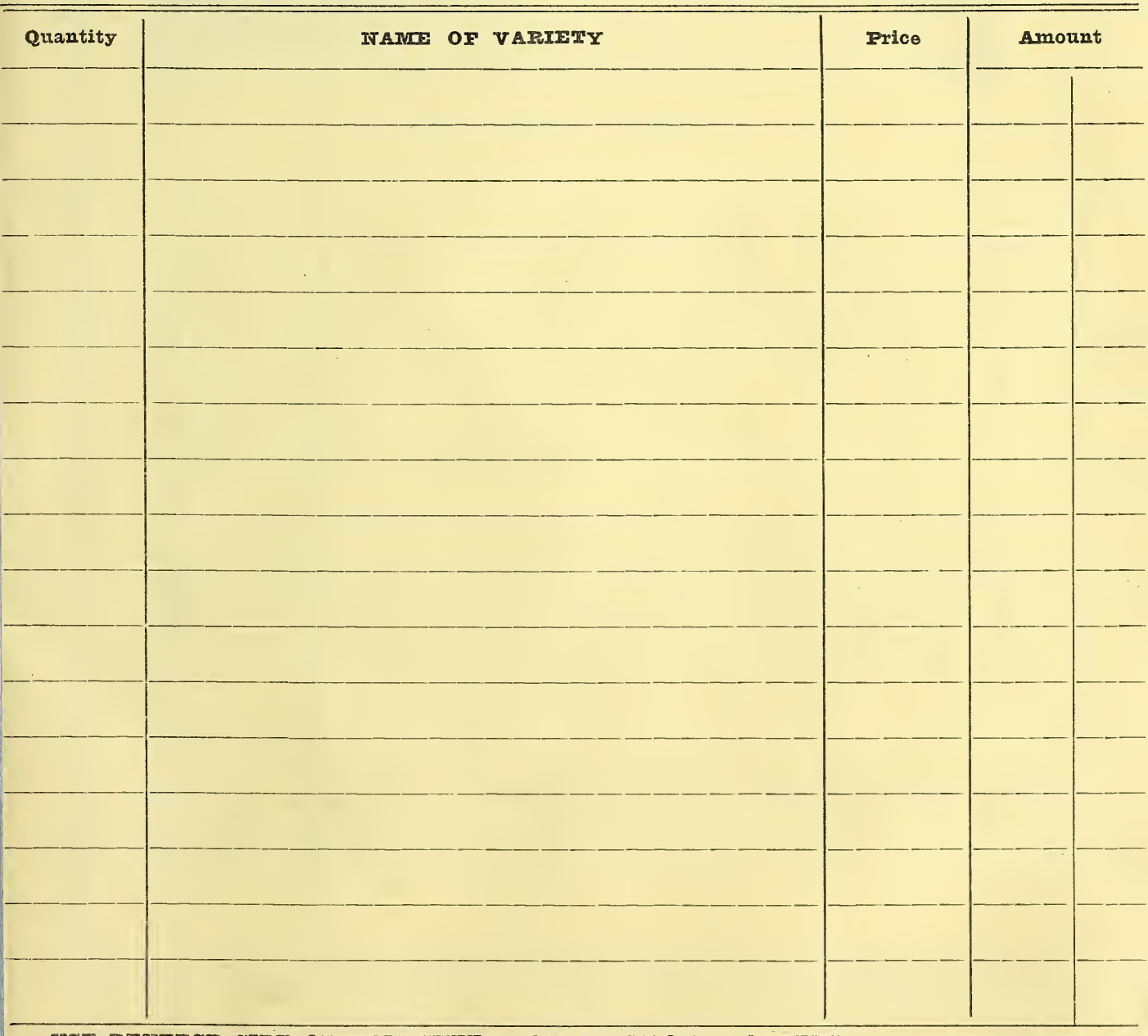




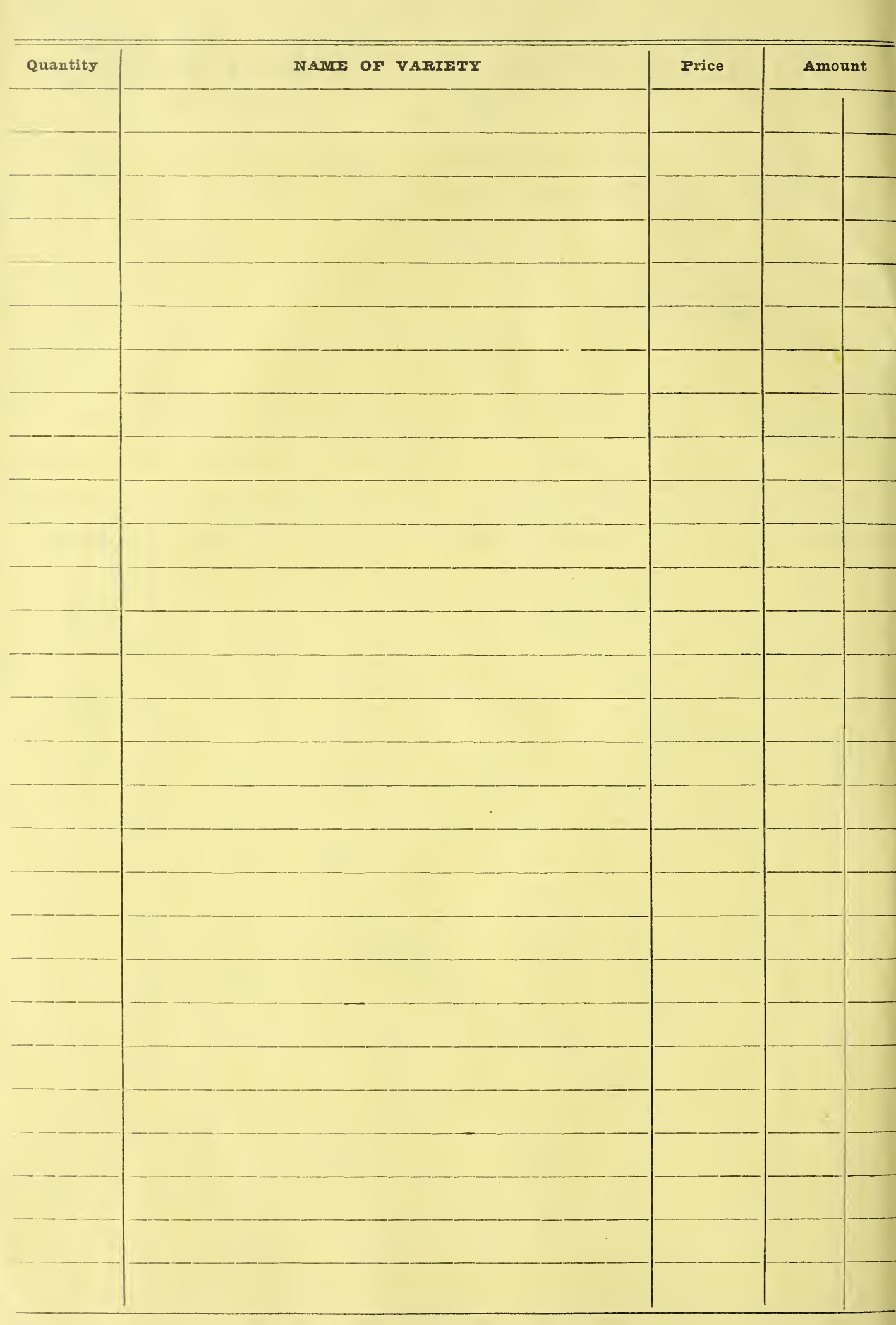


SHADY LAWN NURSERIES : Hugo Kind : HAMMONTON, N. J.

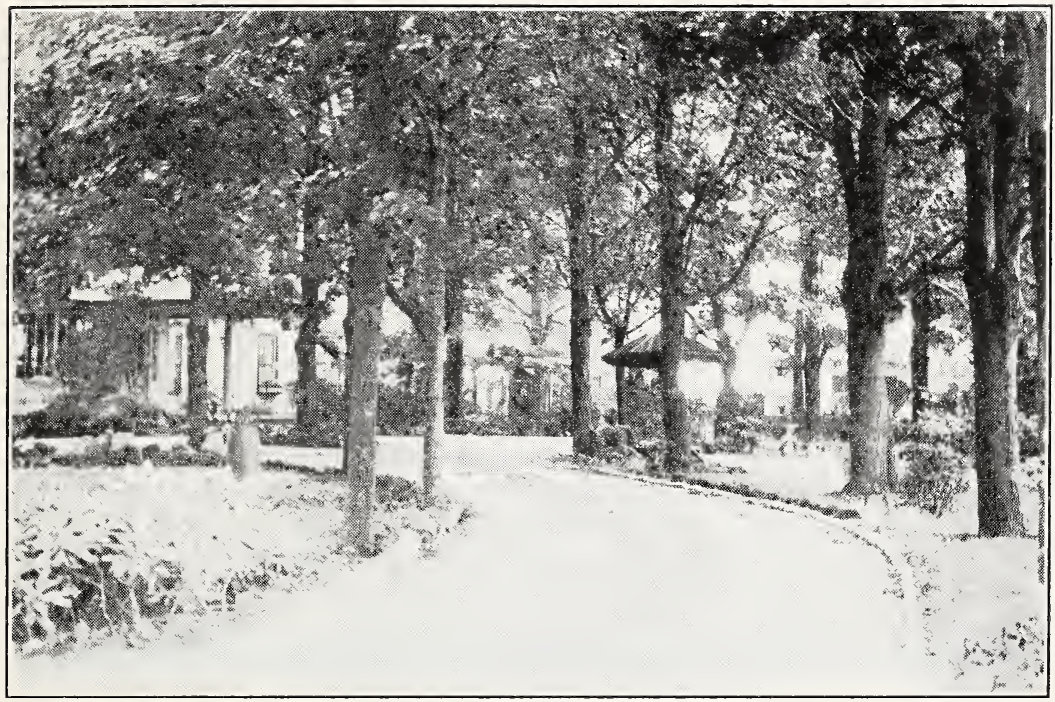

North Entrance to Shady Lawn.

\section{TO OUR CUSTOMERS :}

Our foremost thought has been Quality, and Dahlias has been a life-long study with us and is our Specialty.

It has not been our policy to send our list broadcast, but to cater to those who appreciate Quality and Service.

Personal attention to all orders, large or small.

Prompt shipments.

Immediate reply to all correspondence.

Advice cheerfully given.

Hammonton, "The Hub of South Jersey," is located half way between Philadelphia and Atlantic City on both the Pennsylvania Railroad and the Reading Railroad. There are many express trains direct to both points as well as direct service to New York. We extend to you a cordial welcome to a visit any time of the year. Time tables will be sent on request and it will be a pleasure to meet you at the station. Our Nursery is just two and a half miles from the depot.

\section{TO MOTORISTS}

The extensive "White Horse Pike," a concrete road in direct line from Philadelphia to Atlantic City will bring you within one half mile of our place. Ask any traffic officer or resident when reaching Hammonton and they will gladly direct you to our Nursery. 


\section{Please Read Before Ordering}

\section{BUSINESS TERMS}

Cash Only. A special 5 per cent discount on all orders on bulbs (packing free) of $\$ 10.00$ and over. No discount on C. O. D. orders. As to my responsibility I refer you to Dunns or Bradstreets Mercantile Agency. To the Peoples Bank of Hammonton, N. J., Clayton Title \& Trust Co., Clayton, N. J.

Though it is seldom we fail to complete accepted orders we cannot be held responsible should we fail to do so.

This list cancels all previous lists and quotations.

Shipping Instructions: Always state by what method you want goods forwarded, otherwise I will use my best judgment.

Claims must be made within 5 days after receipt of goods. All goods travel at purchaser's risk.

Non-Warrant: I endeavor to send out the best quality only, true to name, but I cannot guarantee results. If customers do not accept goods on the above conditions, they can be returned to me within 10 days.

Parcel Post: If you wish parcel post shipment remit sufficent to cover charges. We will return any overamount that may be sent. Or extra bulbs if so desired.

Packing: Packing will be charged at cost unless cash with o-der. For the larger bulb orders we pack in uniform airtight sugar size barrels, which are charged at 65 cents each. No orders accepted under $\$ 1.00$.

Please Order Early and avoid possible disappointment. All orders are booked subject to previous sales.

Early Orders can be placed for later shipping, providing 25 per cent of its value is remitted when ordering. We cannot hold stock later than June 1 .

In the event that we are sold out of certain varieties, we will substitute to our best judgment, unless ordered not to do so.

\section{OUR POLICY}

We do not sell to Jobbers or Department stores.

It is our aim that we supply those that grow direct for the rurpose of growing plants or flowers to sell, or dealers that supply the trade.

If you are not thoroughly acquainted with Dahlias best suited for your purpose, write us and we shall be glad to help you to the best of our knowledge. 


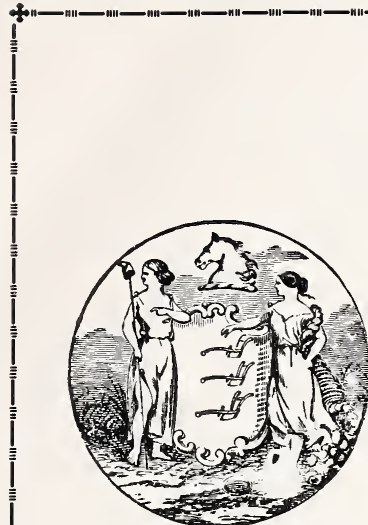

\section{STATE OF NEW JERSEY}

ALVA AGEE, Secretary

Bureau of Statistics and Inspection

HARRY B. WEISS, Chief

No. 45

Trenton, N. J., September 1, 1929.

This is to certify that we have this 8th day of July, 1928 , in accordance with the provisions of Chapter 268, Laws of 1916 State of New Jersey, inspected or caused to be inspected by a duly appointed Inspector the general nursery stock growing in the Shady Lawn Nurseries of Hugo Kind, proprietor, at Hammonton, in Atlantic County, New Jersey, and have found the same apparently free from San Jose and other dangerously destructive insect pests.

This certificate expires June 1,1930 , and covers stock actually in the nurseries when examined.

WM. H. MARTIN,

State Plant Pathologist.

THOMAS J. HEADLEE, State Entomologist.

RALPH B. LOTT, Chief Inspector.

\section{FROM NURSERY CERTIFIED BELOW \\ VIRGINIA DEPARTMENT OF AGRICULTURE AND IMMIGRATION}

Official Tag No. 1474

Richmond, Va., November 23, 1929.

This is to certify that the certificate of a duly accredited inspector has been fled in this office stating that the premises of Shady Lawn Nursery, Hugo Kind, Hammonton, New Jersey, were examined season 1929 and that the above mentioned certificate conforms to laws and regulations in force in this State.

This tag expires August 31, 1930. Issued on certificate of

T. J. HEADLEE,

State Entomologist.
G. T. FRENCH, State Entomologist and Plant Pathologist.

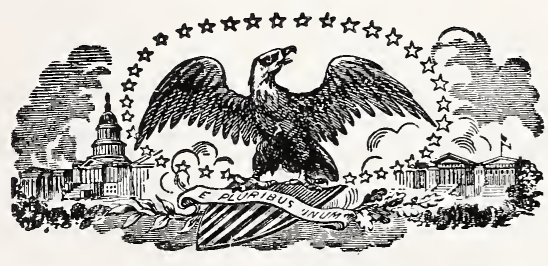

Note-U. S. Federal Inspection

It is our custom to have Federal Inspectors, during shipping season, look over and carefully inspect our stock daily. All shipments undergo a rigid test. All stock so passed is labeled with the U. S. Department of Quarantine certificate.

\section{SPECIAL RASPBERRY CERTIFICATE No. 2}

$$
\text { Trenton, N. J., July 30, } 1929 .
$$

This is to certify that the raspberry plants, roots or tips offered for sale by Hugo Kind of Hammonton, in Atlantic County, New Jersey, have been inspected in the field and found practically free from mosaic, leaf curl, rosette and similar diseases.

EDGAR G. REX, Chief Inspector. 


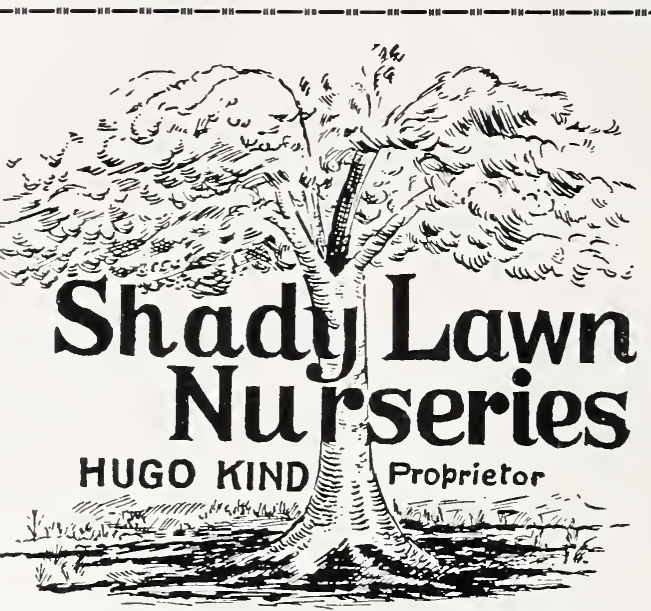

ffect frozen juices to the bulb and what is known as dry rot will most always set in. Dahlias are best stored in a damp They can also be stored in barrels or boxes, but left open until all excessive moisture has left the roots. Covering to keep them from shriveling may be placed on them after January.

All Dahlias here listed are grown at our grounds at Hammonton, N. J., tried out and thoroughly rogued. Though we make no claims that the varieties listed are the choice of Dahlias, we have made up this selection for the wants of our customers. Kinds and varieties as to the best is entirely psychological and we leave the matter of choice to the buyer.

\section{Dahlia Cultural Directions:}

Clumps should be cut to single eye divisions. If sprouted cut the sprout within a quarter of an inch from the bulb.

They should be planted in rows of five feet apart and two to three feet in the rows. The best method is to lay the bulb flat (not stand) and cover with three inches of soil. If a row six inches deep is struck and bulbs planted three inches the row can be filled in from time to time. When the pllant has attained a height of about eight inches pinch out the top. This will enable the plant to sprout and give proper flowers. A second pinching may be made in the early August. Not later. Disbudding of the side shoots is very essential. This will give you the fine exhibition flowers. We suggest five to six flowers to the plant. Flowers cut in the morning hold up best. Place in a cool cellar away from draft. Slightly syringe the flowers, this will stiffen them.

In rich soil fertilize slightly. In poor soils over fertilization can hardly be accomplished. Bone meal, manure, or any good potato fertilizer is essential.

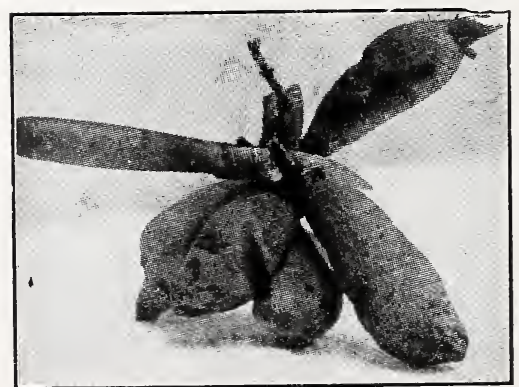

Cut (greatly reduced in size) showing practical methods of dividing. The crown (note knife) can also be split with good results. 
SHADY LAWN NURSERIES : Hugo KiND : HAMMONTON, N. J.

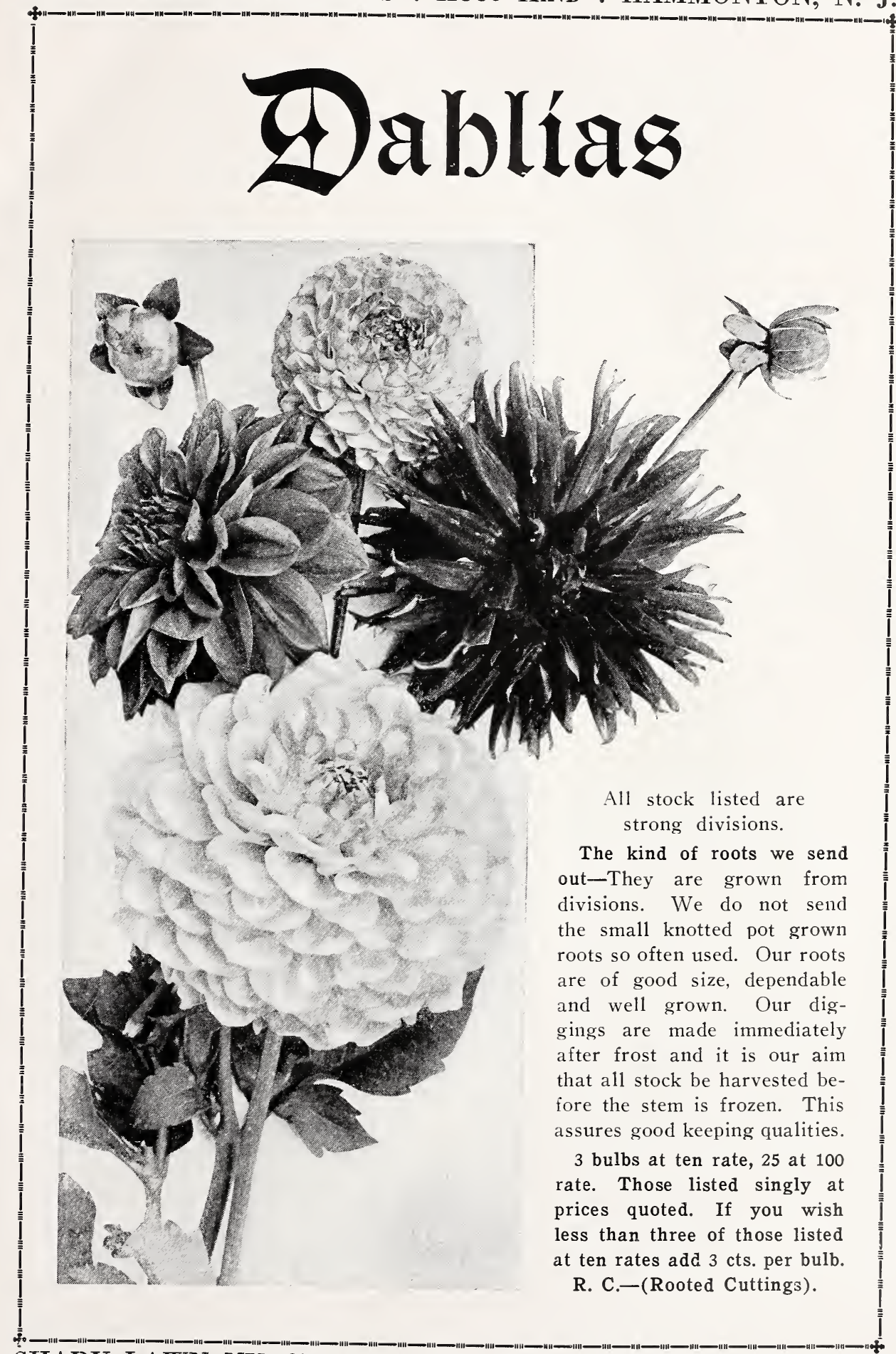

SHADY LAWN NURSERIES : HUGO KIND : HAMMONTON, N. J. 
SHADY LAWN NURSERIES : Hugo KIND : HAMMONTON, N. J.

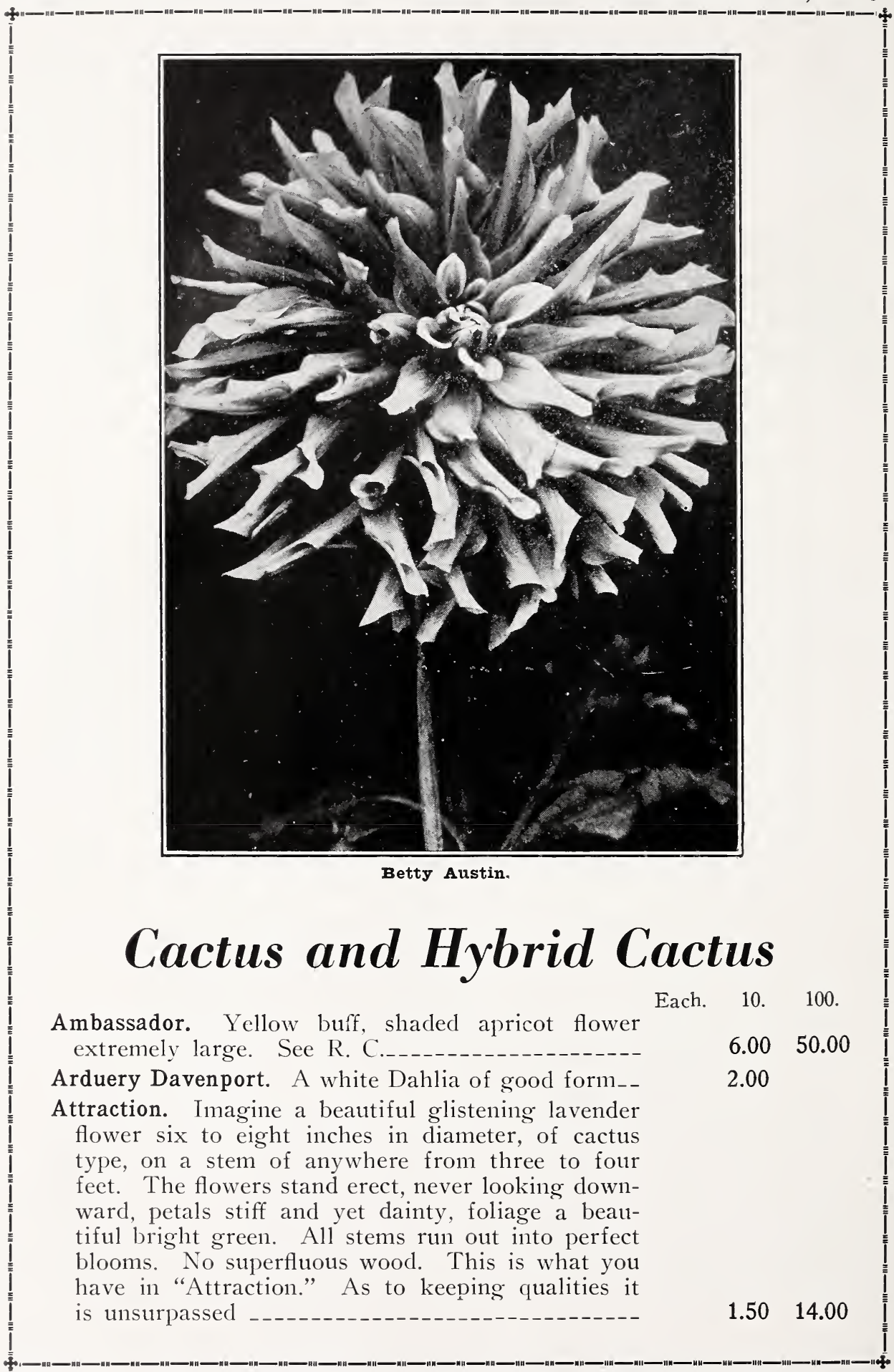

SHADY LAWN NURSERIES : Hugo KIND : HAMMONTON, N. J. 


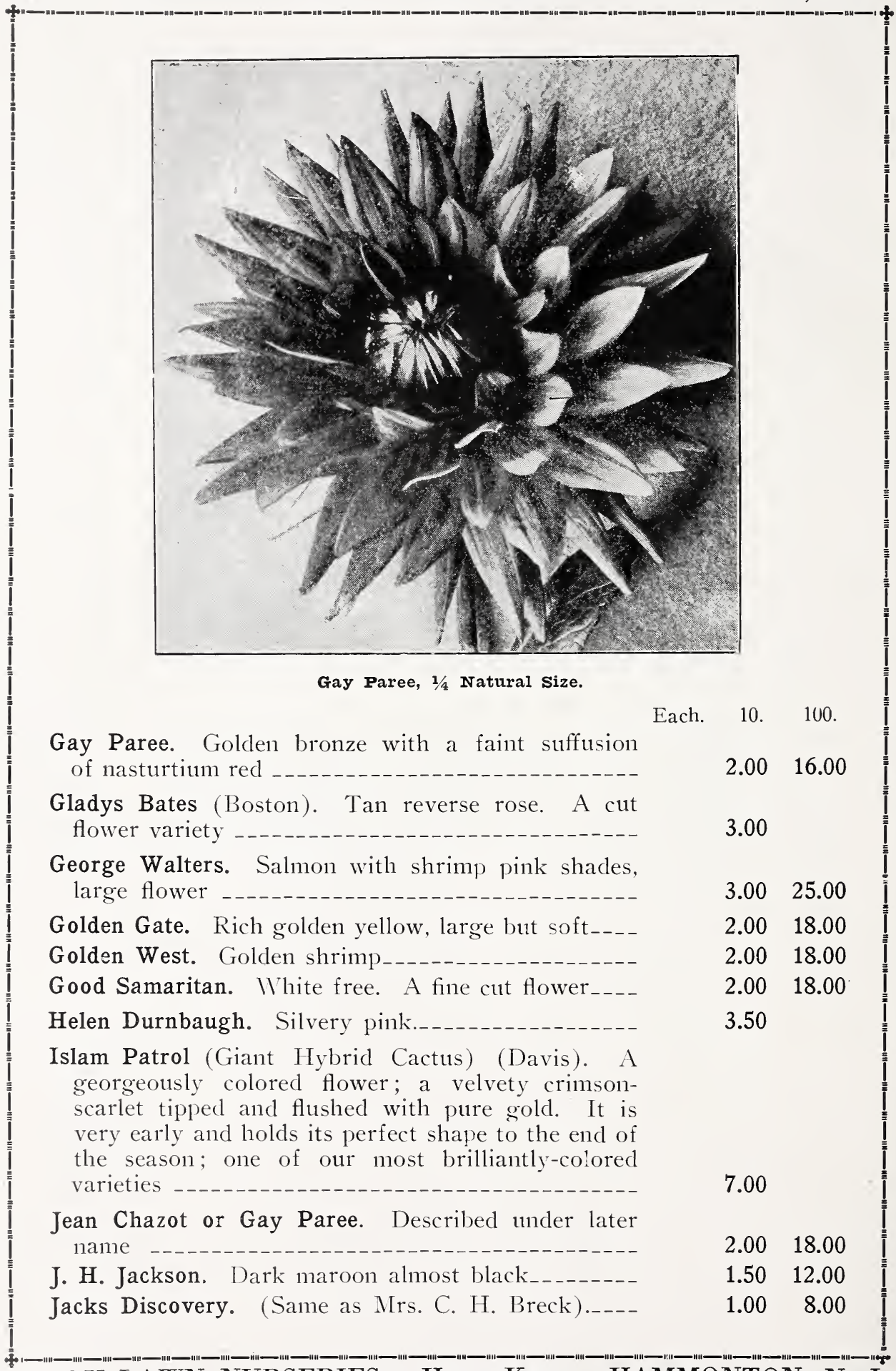


SHADY LAWN NURSERIES : Hugo KIND : HAMMONTON, N. J.

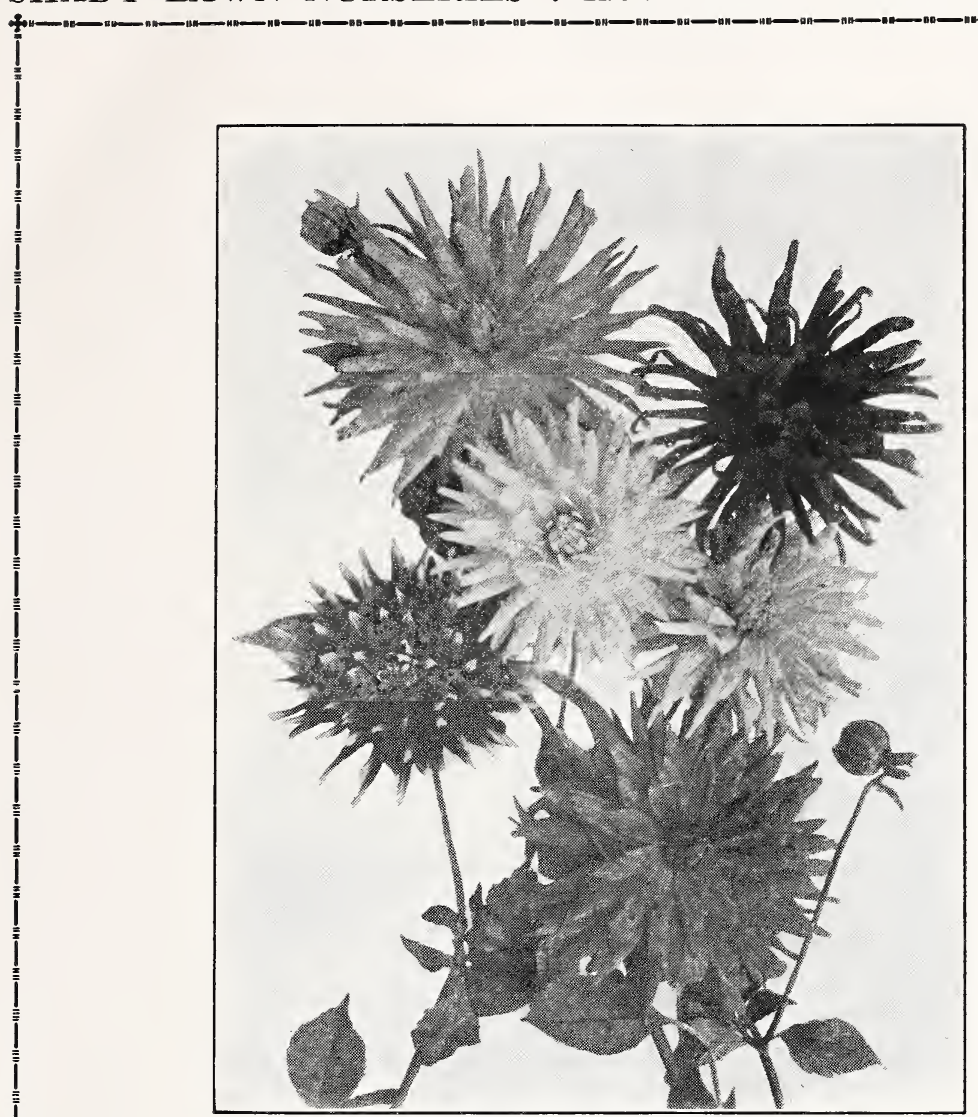

True Cactus Dahlias.

Kalif. Vivid turkey red, good stems. One of the

Each. $10 . \quad 100$. best.

Lady Swathling. Pink

La Favorita (H. C.). Brick orange

Lawine. White with slight suggestion of lavender, good cut flower _._-_-_-_._-

Leo XII. Sulphur yellow

Libelle. Dark purple, free bloomer_._..............

Lolita Velasco (Bessie Boston). Pure white large, fine form, good stem.............

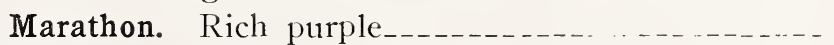

Marguerite Bouchon. Pink tipped white_.......-

Marie Doucett. Light pink__._._._._.

IMariposa (H. C.). Pink suffused violet_........... 


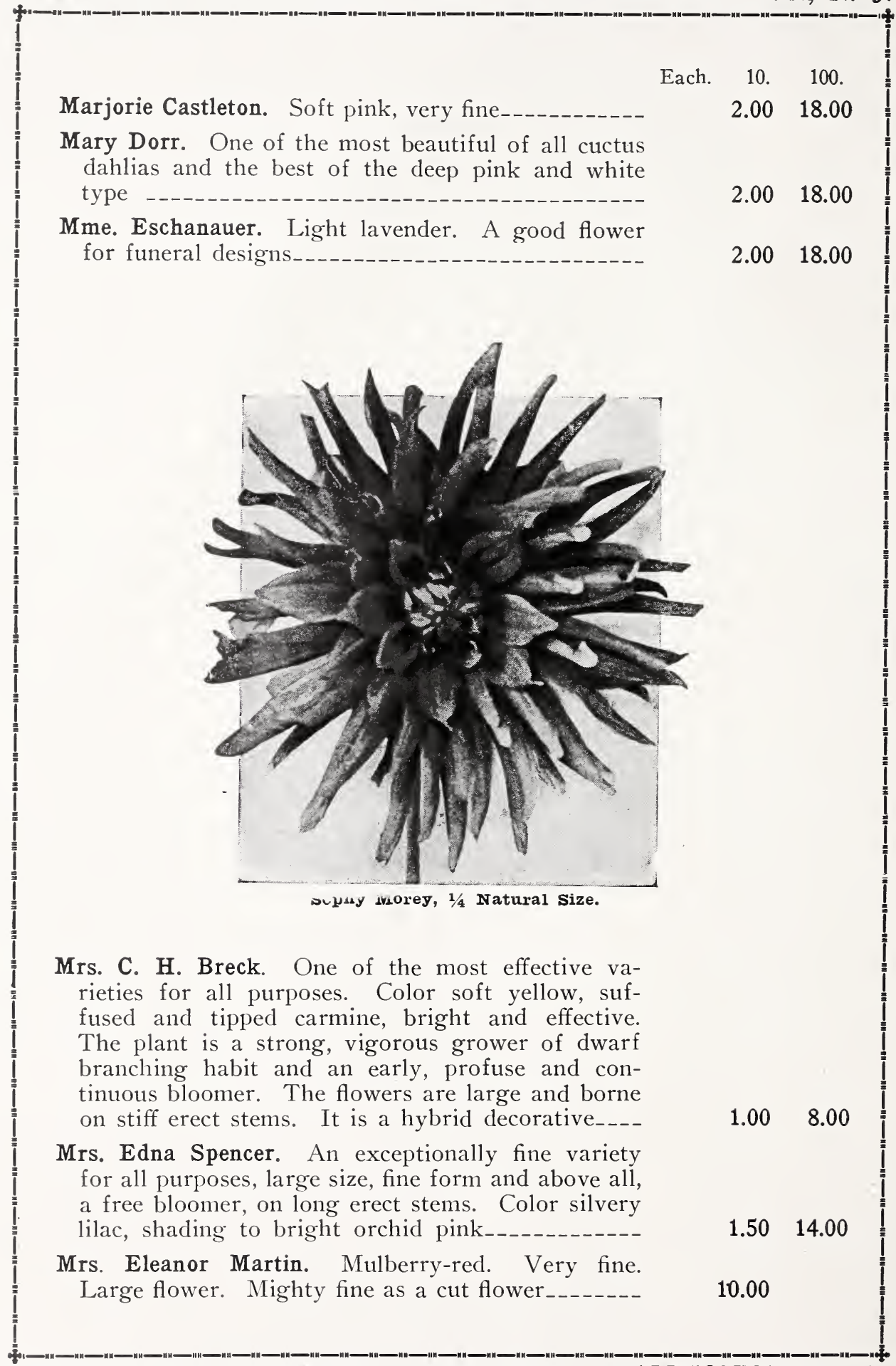


Mrs. Leo Niessen. Gorgeous autumn shades, yellow

Each. 10.100.

at base suffused and tipped a rich bronzy red----

Mt. Shasta. Light flesh pink

2.50

Mother (Peacock). A white Dahlia of good form and size

Mrs. Kathryn Donges. A large flower of excellent form. Yellow, shading darker toward end of petals. A fine keeper and free bloomer for such a large flower

Nibelungenhort. Sun flower yellow tipped with rose-

Norman. Red

Papillon (H. C.) (Bessie Boston). Light old rose with yellow shading, very large, good form, free bloomer, strong grower, highly recommended-----

Perle de Lyon. Pure white, robust

4.50

45.00

1.00

Pierott. Deep amber, usually tipped white large----

Pink Pearl. Bright rose pink, tipped white; fine form, an early and profuse bloomer

1.00

Prince of Yellows. There is no yellow dahlia that gives the profusion of flowers that equals this variety. Well for bedding

Rene Cayeaux. Red, free

Rheinischer Frohsinn. A most distinct and refined variety. The flowers are large, of splendid form; the long, incurving petals are white at the base, but about one-half their length they become suffused with and change to a luminous carmine rose a high class cut flower

Rio Rita. Red and Gold

Robert Groff. The finest hybrid cactus of the day. Color same as Attraction. In size far superior. Ten inches is common. Stems long. Keeping qualities excellent. R. C. only

Rube Girl. A bronze and yellow effect

Sequoia. Fawn yellow, free, a cut flower variety

Skagerrak. This beautiful clear, clean lemon-yellow has flowers which under ordinary field culture, without disbudding measure 7 in. in diameter. In form it is all that can be wished for, the long petals making a deep gracefully shaped flower, always full to the center.

Snowdrift. White, large and fine 
Sophy Morey. Cactus of most wonderful coloring. White heavily overlaid lavender. A most desirable sort for cutting. A color that is rarely found in cut flower sorts. Do not fail to have at least a row of this variety for your trade

Springfield. Red overlaid salmon

Success. Yellow

Sunset Glow. It is larger than Red Cross and better color; it is always perfect in form and will produce several times as many flowers. The color is yellow at base of petal, outer part overlaid flame scarlet, tipped yellow. The plant is one of the very first to bloom, of medium height, 3 to 4 feet and branching habit. It is an extremely profuse bloomer and every flower is perfect. As it is larger and better colored than Red Cross, it is not only the best of this type for garden and commercial cut flowers, but a splendid exhibition bloom_-_-_-

Sunshine. Red with yellow shadings, fine cut flower

Sweet Briar. Pink, fine for cutting-_-_-_-_-_-

Thais. White shaded lilac_-_-_._-_._-

Tom Lundy. H. C. Valvet red. A California favorite

Theodore Roosevelt (H. C.). A new and very attractive dahlia that we listed for the first time last season. The flowers which are borne on long stiff stems are a beautiful shade of yellow. Each petal is finely curved and reflects to the stem as the flowers fully expand. Different than most other dahlias in this respect. It is of a hybrid cactus variety. 8 to 9 in. across. Keeps a long while after cutting.

Valiant. Crimson --_-_-_-_-_-_-_-_-_-_-_-

Wacht am Rhein. Hydrangea pink, tinting to a white at center, good, straight stems and fine for cutting

Wasco Beauty (Peoney Cactus). Large varigated flower composed of shaggy incurved petals of a pretty Geshia color

Washington City. Snow white, of beautiful form and borne on long stems. The flowers are of enormous size

Wodan. Old gold at center, shading to a salmon rose. This variety is in a class by itself, insofar as it is an extremely vigorous, almost rampant grower, producing the big flowers profusely on very long stems. Soft 


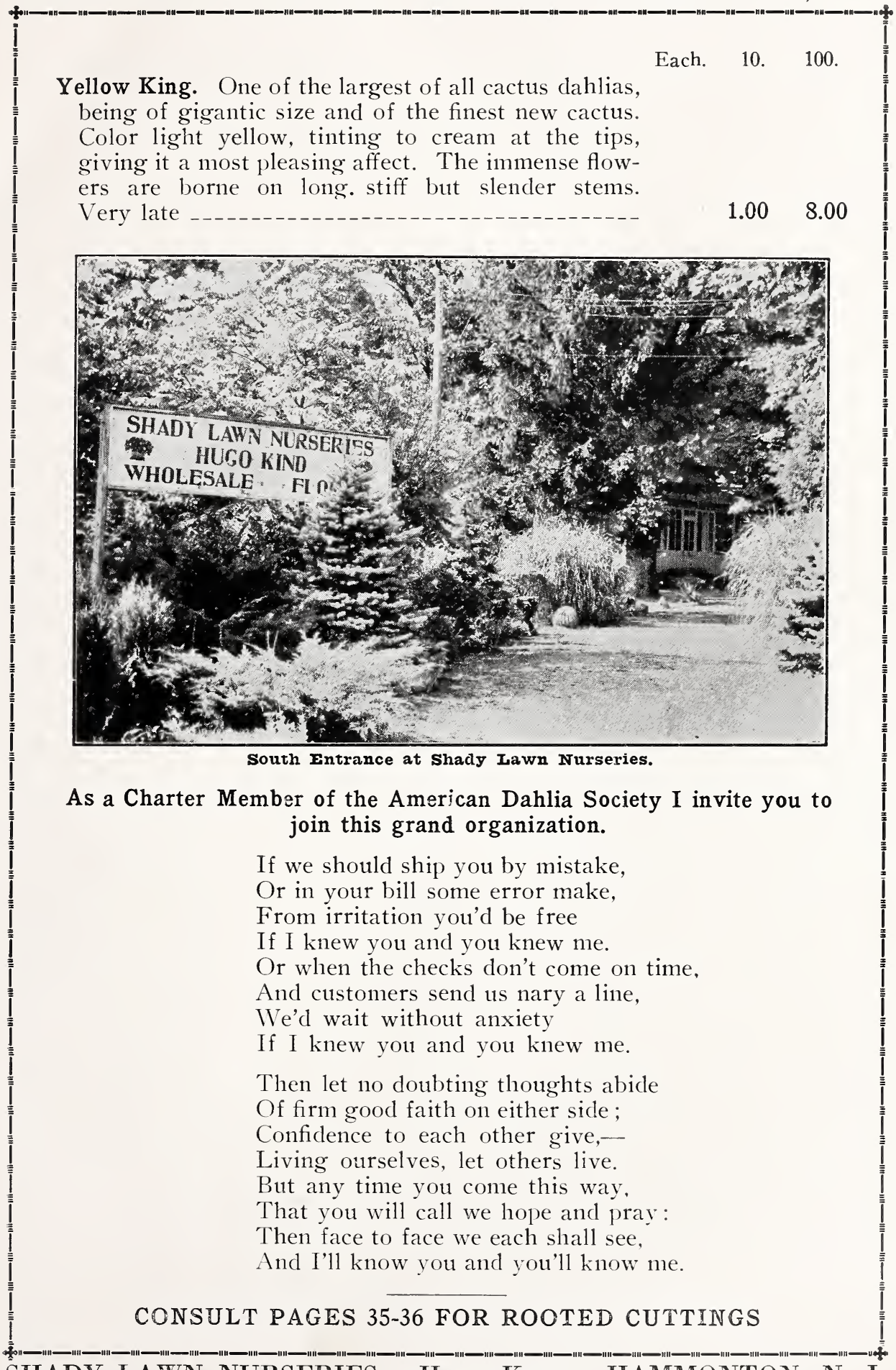

SHADY LAWN NURSERIES : Hugo KiND : HAMMONTON, N. J. 


\section{Decorative and Hybrid Varieties}

Adda Patterson (H. C.). White. Large and fine.

Each. 10. 100.

Worth trying as an exhibition flower. R. C. only.

Admiral Dewey (Peony Dec.). Giant fluffy flower, bronzy yellow with red suffusion_-_-_-_-_-_-_-_--

Aida. Giant deep maroon. An exceptionally fine dahlia. -

Alice Witte. A free white. Similar to Princess Juliana.

Albatross. A very large white on long stems. Poor

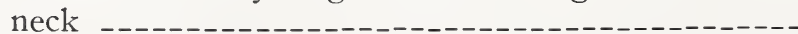

Amityville. Large light silver pink; extra fine.-----

Amarillo Grande. Another large dahlia in the bronze colorings. So many Dahlias are classed in the bronze shades that it is considered best to give them a trial as they are truly all different.

Amon $\mathrm{Ra}$ (Seal). An immense decorative of coppery bronze; the stems are long and stiff and the flowers keep splendidly when cut_-_-_-_-_-_-_-_--

Amulet. Large and fine. Red_-_-_-_-_-_--_-_----

Arbutus. Large fine decorative of the Arbutus coloring. A coming cut flower and equal to Jersey Beauty. Stems and flowers are extremely large. Great future awaits for this extremely fine sort.

Aurora "B." Dark purple small white collarette like, petals intermingled. Very pretty and new--

Aurore. One of the most attractive dahlias in our collection. Apricot with lovely shadings of peach and red pink. Just a marvelous color very hard to describe

Avalon. If we had to name this sort we would call it Jersey's Yellow, as all the best Dahlias appear with the prefix "Jersey." Chrome yellow. Stems equal to Jersey Beauty. Flowers immense. Ideal in every way. By no means fail to grow this marvelous yellow. See rooted cuttings__-_-_-_-_-_-_-

Ayesha. Light yellow, long stems_-_-_-_-_-_-_-_--

Azalea. Large yellow, shaded salmon, very good. Large

Alexander Waldie. An attractive fawn color

$2.50 \quad 18.00$

Barbara Redfern. We have in this dahlia a forerunner in the bronze shades. The immense flowers are held on long stiff stems. Must be seen to be appreciated. You should not fail to have this variety in your collection. See R. C. List__._-_._-_-_- 


\section{DECORATIVE AND HYBRID VARIETIES-Continued}

Barbara Wear. Of all the lavender shades we have Each. 10.100. here a forerunner. Our prediction is that this variety will supersede all in this color. R. C. only.

Bashful Giant. A large Dahlia in red and yellow. Very pretty ------

Beatrice Slocombe. Variegated, red, old gold and rose pink, considered by many as Slocombe's best introduction

Bessie Boston. Cardinal red, finely cut petals, a beauty

Bloemhoven. Lilac blue, soft_-_-_-_-_-_-_-_---

Bob Newcomb. A true deep decorative, immense size, color between a plum and burgundy; good stems, first-class as to keeping when cut; shown 36 times, 36 first prizes, this year, for vase of fifty at the big show in Los Angeles, with lots of competition

Bob Pleuse. An incurved hybrid cactus, deep crimson with the end of every petal on every flower for about half the length shading to a white; when ever one sees this one, sale made; good stems, free bloomer. See R. C.--_-_-_-_-_-_---

Bonnie Brae. Cream shaded blush pink, very large--

Break O'Day. Listed under cactus

Butterfly. See Fantasie. Known also as Mme. Butterfly

Calvin Coolidge. One of our leading prize winners. Red and white.

California Gold. (Described under Paul Michael).

Cambria. Giant rose pink lighter in center. One of the best of the English dahlias. Always a prize winner

Carmencita. A variegation of red and yellow. Semi dwarf

Casper Ware. Lavender pink of fine form

Catherine Duer. Bright red, poor

Catherine Wilcox. White tipped red

Champagne. In plain words "Champagne color" if you have not forgotten the good old days. Stems are long and flowers solid 


\section{DECORATIVE AND HYBRID VARIETIES-Continued}

Charles Stratton. Of all our Dahlias in the bronze

Each. 10. 100. colors I think this a prize winner, in size it is enormous. The flowers seem endless as to the size that may be attained. Color very difficult to describe. A bronzey base intermingled with yellow. The petals curve most beautifully, giving this Dahlia a wonderful effect. Flowers produced on stems of a yard in length

Charm. Bronze.

City of Trenton. Rich tangerine. Reverse strawberry. R. C. only

Color Sergeant. Salmon bronze (dwarf) R. C. only--

Clare Kulp. Red, slightly intermingled with white. A large, perfect flower produced on very long, stiff stems. A cut flower of fine quality_._._._._._.

Dakota. One of Judge Marean's introductions producing very large exhibition flowers of good form on good stout stems, color a deep tone of rich coralred with coppery suffusion; a good decorative garden variety

18.00

Darlene. Pink, early good

Delice. Rose pink

De Lighted. The flower is large of fine white. Center shows what we may imagine a row of teeth. Reminding one of good "Teddy" when he greeted his many admirers and said "De lighted." If you are a Dahlia fan this variety should be in your collection

Dream. Beautiful pink, a fine flower on long stems.

Dr. Tevis. Salmon rose, very large and a fine cut flower

Dorothy Robinson. A large bronze Dahlia of good form and habit. Long stems. A good keeper and one you should not miss. Said to do best along coast sections

Dusky Princess. Dark velvety background with lighter veins in petals

Earl Williams. Red, striped, white very good. Identical to Nobilis

Eastern Star. Golden yellow with a bronze suffusion. Flowers are borne on long stiff stems. Used as a cut flower. See R. C 


\section{DECORATIVE AND HYBRID VARIETIES-Continued}

Edith Wooster. Beautiful tea rose blend of red and Each. 10. yellow suffusion.

Elkridge. Bronze, large

Ella Rankin. Rosy carmine. Very pretty

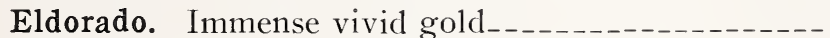

Elinor Vandeveer. Rose pink. See R. C..--_-_-_--

Elite Glory. Considered the extremity in size of the Dahlia world. Red. Stiff stems. Not a free flowering Dahlia which cannot be expected for flowers twelve inches across. Roots of this Dahlia are scarce

Fantasie (Kreist). Bronze with violet reverse. Medium size flower.

Faith Gariboldi. A giant. Deep rose

Faith Slocombe. Old Gold, overlaid bronze and tinted red. Very free, on good stems

Fort Monmouth (H. C.). Rich carmine. A monster. R. C. only

Frank Walker. Early pink

Frau H. Scheiff. Golden bronze. Very attractive and and beautiful

Fordhook Avalanche. White

General Pershing. Creamy white, vigorous flower, poor neck

General Custer (Peoney Dec.). Combination of yellow, white and coral red

Gladys Serwood. White. Very large. Fine_---_---

Glory of Argonne. Delicate violet, rose, shading to

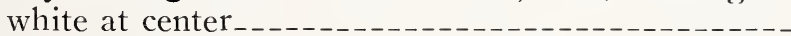

100.

Glory of New Haven. Clear lavender pink, distinctly veined deeper lavender. Very large and free. Useful for exhibition or cut flowers

Grand Duke Alexis. Frilled white

Granadier. Magenta and white

Grizzly. A rich deep dark red. The plant is a vigorous grower and the large, stately blooms are freely produced on extra stout stems. Always a favorite

Halvella. Mallow Pink

Harvard. Large crimson red. A first-class dahlia in every respect.

Helen May Ranken. A pretty dahlia of a lilac rose.

Helen Ware. A very pretty lavender pink. Large and fine 


\section{DECORATIVE AND HYBRID VARIETIES-Continued}

Henry Maier. Yellow suffused amber_-------------

Each. 10.

100.

Henry F. Michell. Fine red_-_-_-_-_-_-_-------

1.00

3.00

Hocksai. Red and yellow, a beauty

2.00

8.00

Hope Moddle. Dark buff with yellow base. Exceptionally good for cutting and for autumn shade decoration

Hortulanus Fiet. Rich salmon pink

Hortulanus Witte. White, free

Insulinde. Rich golden bronze, a beauty

Isabel Street. The flowers are large and are produced on long cane stiff stems. Red and yellow shades. Good

Islam Patrol (H. Cactus). Red and gold. Extremely in demand as a cut flower. Listed also under Cactus

Jack Rose. Jack rose red.

Jane Selby. Delicate mauve pink. Still one of the best California dahlias

Jane Cowl. Similar to that of Insulinde. Upright flower. Very large. Golden bronze. A shade darker than Insulinde. See R. C. list_._-_._-_-

Jane Hall. Yellow. Good Stems_-_-_-_-_-_-_-_-Jean Kerr. Fine white

Jersey Beauty. Hubbard wrote: "When a man builds a better house or makes a better mouse trap than his neighbor the world will make a beaten path to his door." Jersey Beauty has its beaten path to its door. It needs not further introduction

Jersey's Beacon (Wait). Chinese scarlet. Flowers extra large on best of stems. R. C. only_-_-_-_

Jersey's Gem (Wait). Lavender pink. Good.----Jersey's Sovereign. A mighty fine apricot and fawn. Long stems and one of those you should try out for exhibition. R. C. only

Jersey's Ideal. Lavender. Flower large. Long stems. A dandy in every way. R. C. only---...--

Jersey's Masterpiece. R. C. only_-_-_-_-_-_-_-_-

J. M. Evans. A bronze effect. Attractive colorings_ 2.00 18.00

John Merritt. A fine white. Free and a cut flower

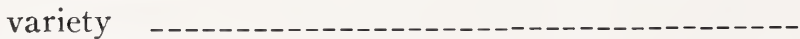

John Sheldon Junior. Large bright pink. Different from most colors of this shade. Flowers to the size of eight inches may be attained, poor neck_-_-_-

J. L. Childs. Yellow, overlaid red_-------------- 
SHADY LAWN NURSERIES : HUgo KIND : HAMMONTON, N. J.

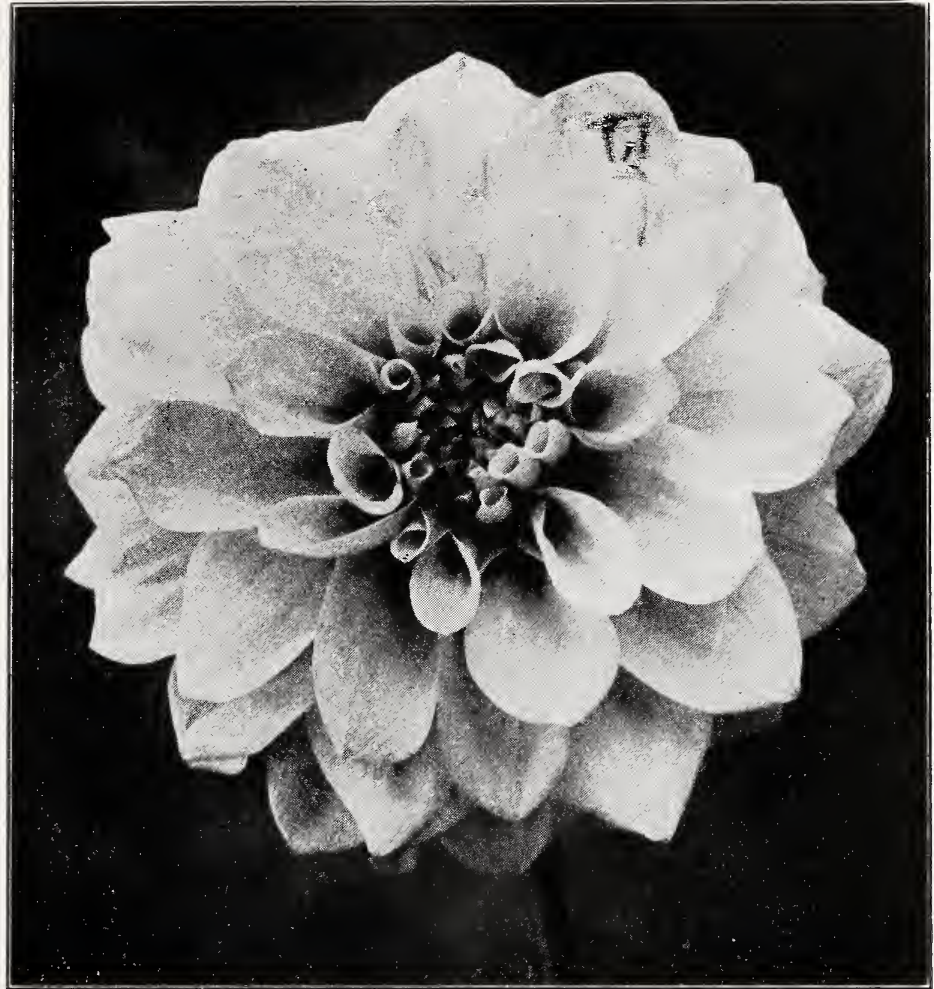

I. Kramer Peacock.

DECORATIVE AND HYBRID VARIETIES-Continued

Each. 10. 100.

J. L. Pennock. Deep maroon. Full center.-_-_-_--

Jessie Prescott. Orange red_-_-_-_-_-_-_-_-_-_-_

Jonkheer Boreel. Soft yellow, shading to golden

amber. Large, splendid form on long, stiff stems.

Exhibition and cut flowers

Judge Marean. A striking shade of old rose. Soft_-

Judge Parker. Bronze. Large and fine_-_-_-_-_-_-

Katherine. It is an immense flower of old mulberry coloring which is intensified by a silvery white at the back of the petals. Stems very long and stiff. Blooms freely the entire season and late flowers are as large and good as the first

3.00

Kemp's Violet Wonder. A prize winner among the violet shades. R. C. only__-__-_-_-

Kentucky (Castlewood). Claimed by Castlewood Dahlia Gardens to be equal to that of Jersey Beauty in habits and form, but of a bronze form. We offer R. C. only 
SHADY LAWN NURSERIES : Hugo Kind : HAMMONTON, N. J.

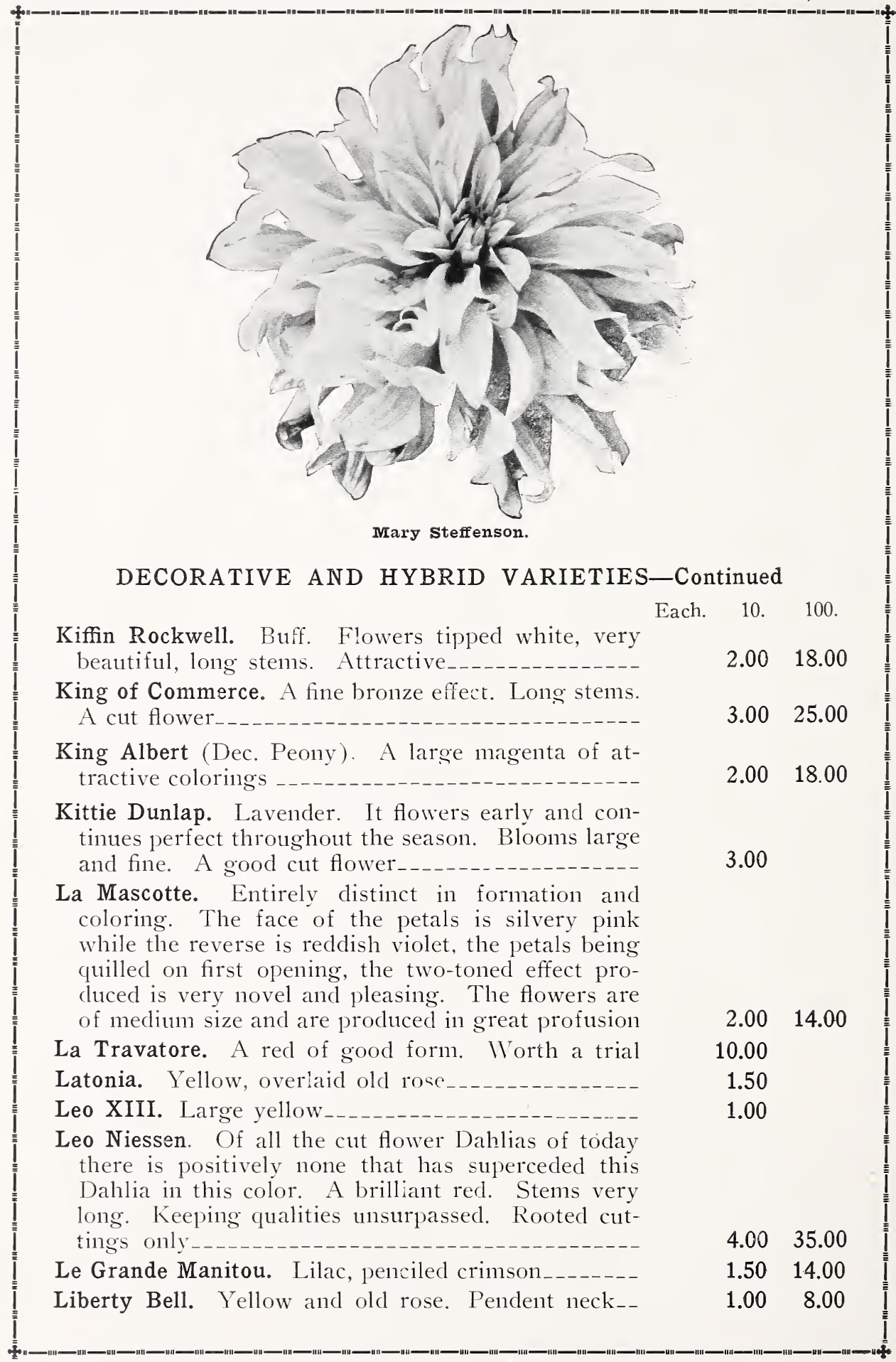


DECORATIVE AND HYBRID VARIETIES-Continued

Each. 10.100.

Lilly Grand. Large white. Very fine._._.......

$3.00 \quad 25.00$

Lillian Baldwin. Magenta rose. Flowers large and fine. Flower inclined to face slightly downward. R. C. only -

L. Kramer Peacock. The flowers are of good size, perfect form, pure white and of great substance, keeping a long time after being cut. The plant is a very robust grower of sturdy, branching habit, and an extremely early, profuse and continuous bloomer

Louise Slocomb. A wonderful reddish garnet. Stems long and fine. Bush vigorous. Flowers keep well after cut. A Dahlia you should not fail to grow--

Maid of the Mist. A deep cream shading to a beautiful salmon-pink on the outer petals which roll back to a depth of four inches, prettily pointed and

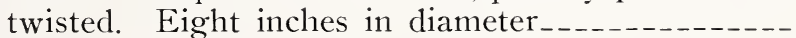

Margaret Dickey. Yellow, fair

Margaret Masson (Fisher \& Masson). Silvery lavender pink, very large, full form, excellent stem, strong grower. Very large striking variety that won many prizes and attracted much attention at this year's show. Highly recommended

Margaret Woodrow Wilson. Lilac lavender. Very large. Exhibition flower. Do not fail to have this for your collection. Most attractive. See R. C.----

Mary Steffenson. Citron yellow changing towards end to rosaline pink

Marmion. Pure golden yellow. Bronze suffusion. One of the winners. R. C. only__._._._._.

Masterpiece. Tango

Melody. Canary yellow, tinting to a creamy white, not a fine flower.-

Mephistopheles. Red base outlined yellow

Mer. Wurfbain. We imported this variety. A dark shade of purple. Rather weak and soft

Mevr. Dagastine. Holland variety. A pretty bronze Dahlia of good form. Flowers upright on stem. A good garden variety though not of importance for commercial use__.___._._._._.

Millionaire. Light lavender flower large, a free grower 


\section{DECORATIVE AND HYBRID VARIETIES-Continued}

Each. 10.

100.

Mina Burgle. This splendid variety was raised by Burgle, gardener at the Mare Island Navy Yard. Color rich cardinal red. It is of fine form. The plant is a strong, vigorous grower, producing freely on long, stiff stems. $5 \mathrm{ft}$. We offer a select strain of roots

Miss Bridgeton. At one time considered the elite in the rose pink shades. It has not been a successful sort with us. Good grower and vigorous...--_-_-

Miss Jessie Seal. Bronze_-_-_-_-_-_-_-_-_-_-_-_

Molly Pitcher (Kemp). Strawberry red. R. C.----

Mont Blanc. A free flowering white

Mons Le Normand. Variegated yellow low tipped white. Sometimes comes solid crimson__-_-_-_--

Mordella. A most charming and stunning bronze fawn. Full and deep. Long stems. Very good. See R. C.

Mr. C. H. Drusselhuis. For many years the variety Delice has been a favorite cut flower, and while beautiful it was not a free-flowering. In this new variety we have a similar color, a soft rose-pink with white suffusion toward the tips, and what is most important, one of the most prolific bloomers; of medium size, right for cutting and are splendidly supported on very long stems. We predict great popularity for this variety as it is undoubtedly the best pink for cutting yet produced_-

Mrs. Atherton (Dec.). Large free blooming of light yellow color

Mrs Cyrus Root.

Mrs. Carl Salbach. Fine pink, long stems, ideal cut flower

Mrs. E. Davie. Light, pink, touches of lavender_---

Mrs. Eleanor Martin. A California sort. Mulberry red. Flower very large. Good stems, but not a tall grower. Very good _-_-_-_-_-_-_-_-_-_-_-_-_

Mrs. G. W. Elkins. Bronze yellow, very large, not a keeper

Mrs. Hartong. Buff yellow, old fashioned._...-..-

Mrs. Helen Hollis. Brilliant red, not a keeper.--_--

Mrs. Hugo Kind. A large flower that is held on long, stiff stems. Of a velvety red and of the most attractive shade. Different than most reds. Petals are irregular and of the most pleasing form_-_---

Mrs. I. de Ver Warner (Marean). Orchid pink, very large, extra stem, strong grower, free bloomer, very satisfactory 
DECORATIVE AND HYBRID VARIETIES-Continued

Each. 10.100.

Mrs. J. Gardner Cassatt. Bright cerise pink, large flowers on long, stiff stems

Mr. J. Harrison Dick. Here is the dahlia supreme for cutting or the garden. One of the most valuable new varieties of recent production. Color citron yellow at center, outer petals suffused and overlaid salmon pink, a lovely and effective combination, especially under artificial light. The plant is a wonderful grower of medium height and branching habit producing the perfect flowers in greatest profusion on long, stiff stems

Mrs. John T. Sheepers. Canary yellow, suffused pink on the outer petals. The huge blossoms are produced with great freedom

Mrs. Louise Finger. White, develops open center at times

Mrs. Lillian Baldwin. Listed under Lillian Baldwin.

Mrs. Nathaniel Slocomb (Decorative). A deep golden yellow of good form on long stems_...-..--

Mrs. Thomas Burch (not the Mrs. Thos. Bush) (decorative). Similar to King of Autumn in form, buff, shaded

Mt. Hood. Pure snow white. Our most reliable white decorative dahlia for cutting

Mt. Shasta. Lister under Cactus. Bronze yellow overlaid tan and canary yellow. A wonderful color combination. Of the hybrid cactus type. The latter predominating. A lovely garden sort_-_-_-_-_-

My Maryland. A very large flower in lavender. Vigorous and free flowering. One of the prize winners in many shows. We offer rooted cuttings only. See R. C.

Nobilis. Startling combination of scarlet and white, with white predominating. Large, bold blossom, on robust stem.

Olive Clive. A lavender similar to Ida ver Warner_-

Orange King. Orange yellow, not a keeper--.-_-_--

Oregon Beauty. Oriental red, large-_-_---_-------

Oyster Bay Beauty. A very lovely red sort in the darker colors. Sometimes equals Elite Glory in size. Free and strong grower. 


\section{DECORATIVE AND HYBRID VARIETIES-Continued}

are ten to eleven inches in diameter without disbud-

Each. 10.

100.

ding. Color is entirely distinct; the buds are a light lemon yellow. As each petal expands the color changes chamelon like, to golden salmon with bronze suffusion (reflex, a beautiful spiral pink. A wonderful vigorous grower, with luxuriant bright, glossy green foliage. The flowers are most beautiful formed with long, irregular twisted and whorled petals, and produced freely on very long stiff stems, entirely distinct.

2.0018 .00150 .00

Rookwood. One of Bessie Boston's favorite introductions, which she describes as follows: "An entirely new shade of pink which is more like the popular Russell rose than any other flower. It is a pure bright cerise rose." Large flowers with excellent stems. Low bushes producing masses of flowers all season. A continuous prize winner.---

Rosa Nell. Deep rose, very large and fine_-_-_-_-_-_

Rose Fallon. Pink and autumn shades. A real pretty sort.

Rosemawr. Large flower of rich rose pink_-_-_-_-_-

Roman Eagle. A large flower in bronze_-_-_-_-_ 2.00

Sagamore. Orange. Said to be the best in its color.

Salbach's White. One of the finest whites in cultivation. Long stems and a good keeper. R. C. only.

Sanhican's Blue Bird. Deep flower of good size. Rather too soft as a cut flower

Sanhican's Gem. Tan and pink. A decorative of the pointed petal effect. A fine flower for fall decorations

$\begin{array}{ll}6.00 & 40.00\end{array}$

Sanhican's Princess. Rose colorings of chaste shades.

$4.00 \quad 35.00$

San Mateo. Best fancy combination of deep yellow, striped and splashed scarlet. A large full flower.-

Senator Baird. Red. Good stems, but nothing wonderful

25.00

Shower of Gold. Golden bronze. Long stems. A very beautiful Dahlia. Petals of Chrysanthemum type

Shudow's Lavender. Lavender._-_-_-_-_-_-_-_-_-

Shannon (Wigginton). Large bold flower in coppery orange

Somerset. Is a large decorative on excellent stems. Keeping qualities of the best if cut when the blooms have fully matured. Blooms freely. In fashioning 


\section{DECORATIVE AND HYBRID VARIETIES-Continued}

s flower the genii of nature have blended the color tones in a manner that makes description difficult. But while the color somewhat varies according to weather conditions and the age of the flower, the general effect is that of salmon and old rose. As the blooms mature, the salmon changes into old rose, and like an after-thought, sometimes, there is a touch of lavender there. There is just a slight twist to the petals and irregularity in the arrayal of same, which gives the flower an air of grace and refinement that is lacking in most large dahlias. Somerset is a healthy and vigorous grower, that you will not need to spray and dust or worry lest some insect give it a cross look. Even Diabrotica (green, black spotted lady bug) will not touch it as long as there is something else to eat in the garden. Somerset has proved its value as an exhibition flower, winning at the Annual Dahlia Show of the Dahlia Society of Southern California in 1923, first prize for the best two-year-old seedling and first prize for the best flower in the show. Scored 90 points. See R. C..-_-_-_-_-_-_-_.-

Souv. de Gus Douzon. Scarlet red, large_-_-_-_-_-Stunner. Giant exhibition flower of an attractive light yellow color.--_-_-_-_-_-_-_-_-_-_----

Susan G. Tevis (Boston). Deep lilac flower with strong stem. Blooms profusely early and late----

Sylvia. Deep pink

Theo Vail. Old gold shading to apricot. Fine for cutting

Tommy Atkins. Remarkable for its wonderful coloring. Brilliant flaming scarlet with golden metallic lustre, the brightest and richest red yet produced. The flowers are very large but not at all stiff or formal and are well placed on good long stems; early flowering and continues good to the end of the season; splendid for exhibition, the garden, or for

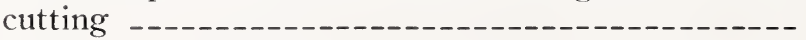

Trentonian. A mammoth Dahlia of fine quality. Excellent for exhibition purposes. Colors are of the autumnal shades. R. C.

Tut. A dahlia that is unusual from other variegated sorts. Yellow, bronze and red. Striped and splashed like a Sioux Indian on the war-path. All colors gayly intermingled. Plant is of perfect growth. Flowers are borne on straight even stems_-_.-.-- 


\section{DECORATIVE AND HYBRID VARIETIES-Continued}

Each. 10.100.

Typhine. Bronze and Red

U. S. A. Very large, red orange

Venus (Marean). Cream white tinted lavender, medium size, good stem, dwarf grower, free bloomer

Vineland. Large flowers of an orange yellow overlaid bronze. Sometimes inclined to come paeony flowered when too it is a beautiful flower.--------

Waldheim Sunshine. There are many yellow Dahlias I must confess this has been our largest in the hybrid decorative. Well known among all exhibitors. See R. C.--_.-.--

Watchung Sunrise. Another close competitor of the above. Extremely large, though the flowers predominates in yellow it is well overlaid with a marvelous shade of old gold and pink.

Watchung Sunset. Grand flower. Mammoth in size. Like the sun setting in the Watchung Mountains. Pink in all its grandeur.

Wm. Reed Butler (not the Daddy Butler). A free

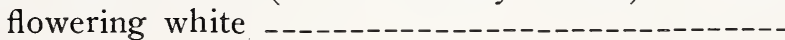

Whopper. A giant decorative with extremely large, well-built deep flowers of a most pleasing shade of yellow-buff, suffused with orange. In form it is all that can be desired

Wizard of Oz. A great dahlia from all points of view, size, formation, color, habit of growth and freedom of bloom. Really a wonderful all around dahlia, be it for the garden, exhibition or cut flower. Begins to flower early and holds its blooms perfect to the end of the season; these are produced on long, stiff stems held so as to show them off to the very best advantages. In color it is a rare shade of amber-pink with soft salmon shading or suffusion. Always attracts great attention. See R. C.--

World's Best White. Considered by some the best white. R. C. only

Yellow Collose. Bright yellow

Yellow Duke. Primrose yellow

$1.50 \quad 14.00$

$1.50 \quad 14.00$

Zeus (Decorative Paeony). This bloom was 101/8 inches in diameter and 5 inches deep. It has not only size and a cane stiff stem, but beautiful form. The color is a wonderfully rich glowing red, each petal distinctly tipped yellow. A giant without a 
DECORATIVE AND HYBRID VARIETIES-Continued

Each. 10. 100.

trace of heaviness. So artistically built and richly colored that it attracts, it holds, it fascinates. The plant is medium dwarf, 3 to $4 \mathrm{ft}$. high, as we grow it in field; strong, sturdy, healthy and vigorous.

A free and continuous bloomer. See R. C._._...- 1.50

Zikola. Free flowering bronze good cut flowers_--- $\quad 2.00 \quad 18.00$

\section{Show or Ball Dahlias}

A. D. Livoni. Shell pink, free, early

Each. 10.100.

American Beauty. Probably the best red in this class.

Flowers immense for a show dahlia. Resembling well its name. Do not fail to grow this dahlia in

your "show" collection__-__-_-_-_-_-_-_-_-_-_-_

Aurora. Yellow shaded bronze_....._._._._._._. 1.00

Crimson Globe. Crimson 1.00

Cuban Giant. Garnet____._._. 1.00

D. M. Moore. Large dark maroon

$1.50 \quad 12.00$

Dreer's White. Large white. Free and early_----- 1.00

Dreer's Yellow. Golden yellow, fine

Elsie Burgess. Lavender

E. P. Jewel. Garnet_-__.

Enchantress. Pink

Elm City. Bronzy yellow, suffused amber and tipped red

Fireburst. Bright red

Gold Medal. "Kind's Gold Medal." Of all the show Dahlias we have, here is a Dahlia all by itself. The reader may recall the older variety of Gold Medal. A yellow base with markings of bronze. Ten years back we found a sport from this particular sort which proved to retain its character. The color is of a most pleasing coppery bronze. Many of these flowers are shipped to the New York and Philadelphia markets. A color always wanted by the decorator. Consult your wholesaler as to his opinion on this particular Dahlia. Through a misunderstanding this Dahlia was given other names as "Gold Medal De Luxe," etc. There are the three strong points why you should have this Dahlia in your collection: A most desirable color, long sturdy stems, always in demand 
SHADY LAWN NURSERIES : Hugo KIND : HAMMONTON, N. J.

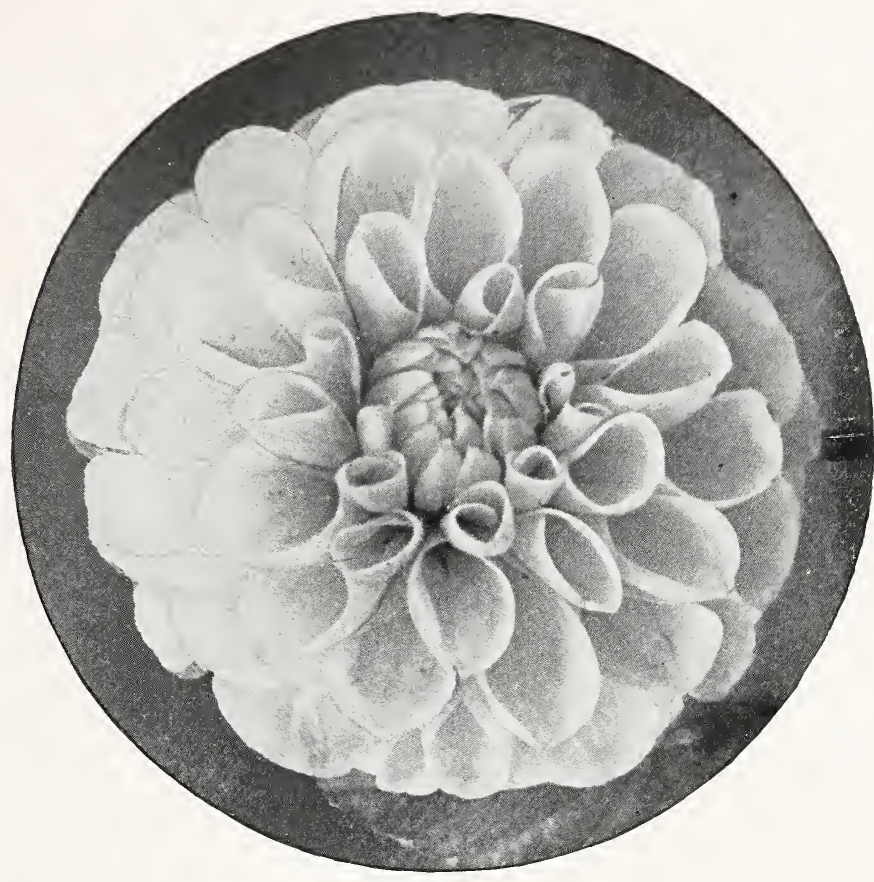

SHOW or BALL DAHLIAS-Continued

Each. 10. 100.

John Thorpe. Lavender pink

8.00

Lemon Beauty. Lemon yellow, long stems

Maude Adams. White and lilac, suffused, flower soft.

Mme. De La Moure. Cerise pink, free and fine, red markings

Mrs. Roosevelt. Pink

$1.50 \quad 12.00$

Peacock. A combination of lavender blue and white.

Very attractive. The best of this type-

Progressive. Lavender pink

Queen Victoria. Yellow

Red Grand Duke. Cardinal red

Rose. Rose pink, long stem, not a keeper.......--

Snowdon. White, not a keeper-_. 1.00

Stradella. Pure magenta _.......... 1.00

Vivian. Old rose and white 


\section{SHOW or BALL DAHLIAS-Continued}

Wagner. Probably the largest show dahlia in our

Each. 10.100. collection. Immense flower of a chrome yellow shading deeper at ends. A prize winner for size, poor stem ---.--

White Swan. White, free-_ 1.00

W. W. Rawson. White quilled petals suffused lilac--

\section{Single or Century Dahlias}

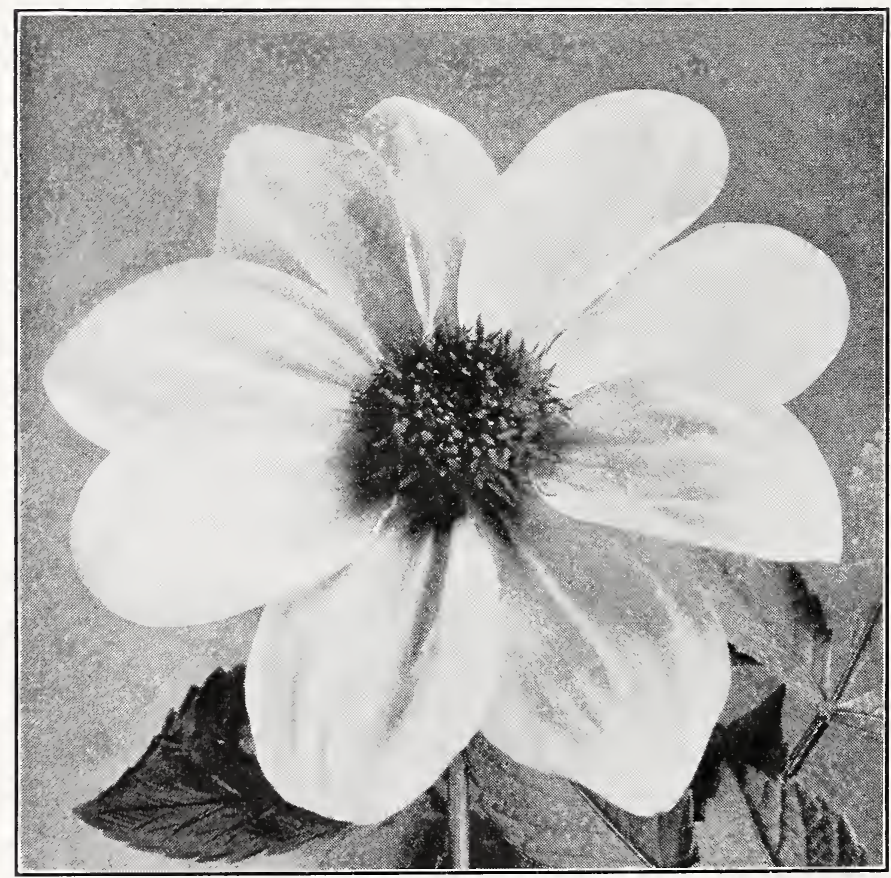

Rose Pink Century.

Each. $\quad 10 . \quad 100$.

Alva. Yellow, speckled and tipped with pink

Ami Barillet (Lucifer). The purple foliage Dahlia.

Entirely distinct. Flowers pure garnet, rich and glowing with a dark center, until the pollen appears. A free bloomer and strikingly effective for

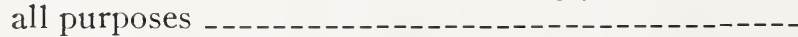

Apple Blossom. Pretty single apple blossom shades. Autumn Century. Old rose and yellow_-_-_-_-_--Ceres. A good pink 


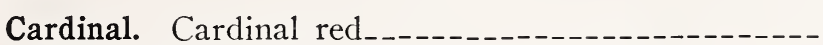

Cream Century. Creamy white

$1.00 \quad 8.00$

Fedora. Bright yellow, heavily striped bright-red---

$1.00 \quad 8.00$

Fringed 20th Century. Pink, shading to white, fringed petals

Geisha Century. Red and yellow

Gloxinia. In marking and brilliancy of color resembles the gloxinia so much to suggest the name-

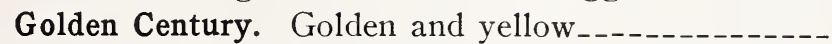

John Lucas. Apple blossom pink and white. Very large flower

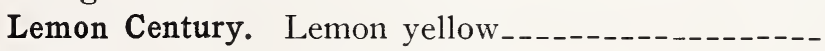

Lucifer. Known as Ami Barillet

Nymphea Century. White yellow toward center.---

Praxiteles. Maroon tipped white, fine

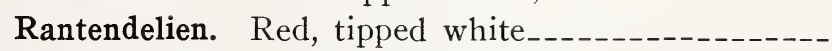

Rose Pink Century. Rose. The finest of all Pink Centuries

Sachem. A beautiful orange-scarlet--_-_-_--_-----

Scarlet Century. Scarlet.

White Century. White

\section{Collarette Dahlias}

Albert Maumerne. Velvety crimson, purple with white tips _-_-_-_-_-_-_-_-_-_-_-_-_-_-_-_-_-_-_

Banker. Rich scarlet, collar petals scarlet tipped yellow

Each. 10.100.

Diadem. Red

Dorian. Rich crimson, shaded maroon; collar white-

Elgrave. Duplex collarette, most novel and effective, with two or more rows petals; rich maroon, collar petals maroon heavily tipped white

Fayette. Bright scarlet with light yellow collar_._-_-

Marley. Yellow and old rose_-_._-_-_-_-_-_-_-_

Maurice Rivor. Rich crimson maroon.

Mons. L. Ferard. Carmine, white and purple collar_

Prince Carnival. Very large and fine. Soft rosy red-like color

Traymore. Red, yellow collar.

$1.00 \quad 8.00$


SHADY LAWN NURSERIES : Hugo Kind : HAMMONTON, N. J.

\section{Peony Dahlias}

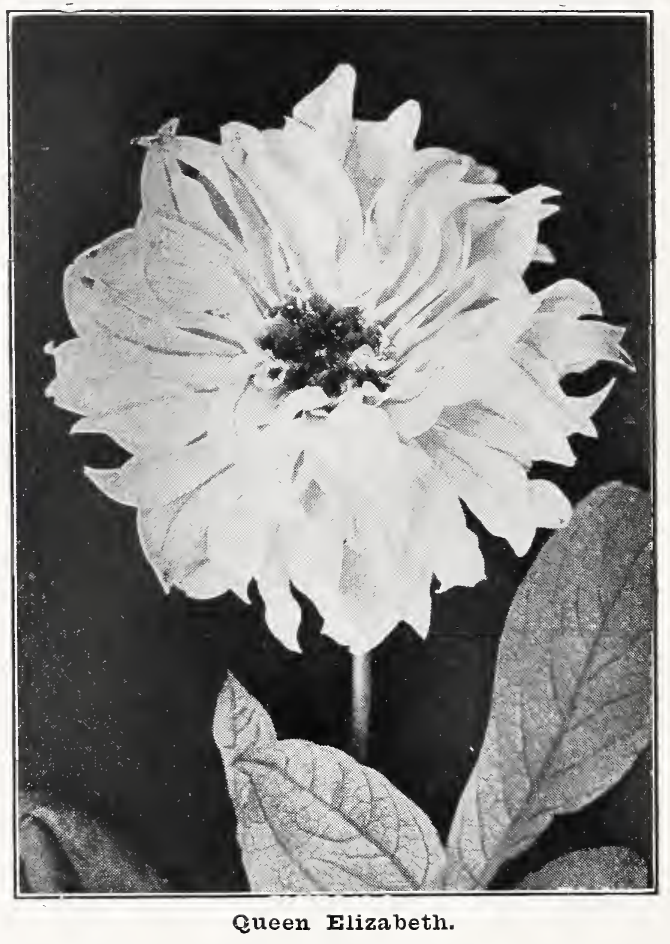

Each. $10 . \quad 100$.
A. C. Ide. Dark garnet
1.00
8.00
Andrew Carnegie. Salmon pink
$1.00 \quad 8.00$
Big Chief.
1.00
8.00
Canada. A fine fluffy white
1.00
8.00
Chateney. Pink
$1.00 \quad 8.00$
Cleopatra. Red and yellow
1.00
8.00
Devotion. Large pink, free
1.008 .00
Diana. Dark red, large
Glory of Baarn. Lavender.
$1.00 \quad 8.00$
$1.00 \quad 8.00$
Glory of Nikerk. Deep claret purple
1.00
8.00
Mrs. Jacques Futrelle. Yellow, heavily splashed scarlet
$1.00 \quad 8.00$
Mrs. Ellen Kelley. Yellow
Mary Jane. A fine flesh pink
Mme. Biestin. Lavender, free 


\section{PEONY DAHLIAS-Continued}

Mrs. Charles Seybold. Red tipped white

Each. $10 . \quad 100$.

Nokomis. Yellow, heavily striped red, a showy and fine flower

Pride of Portland. Yellow and red

Princess Juliana. White free bloomer. A fine cut flower

Queen Elizabeth. The lavender that has not yet been beaten. Long stems, free bloomer, a fine flower indeed

Queen Emma. Hollyhock pink.

Queen Wilhelmina. White, free

Souv. de Lietz. Dark red_

William Kerr. Red and yellow.

\section{Pom Pom Dahlias}

Allie Morey. Rose

Each. 10.

100.

Amber Queen. Flower large, amber____..._._. 2.00

Ariel. Orange buff, extra fine small flowers_-_-_-_-

Carona. White, not a free bloomer._._._._. 2.00

Catherine. Bright vellow__. 1.00

Clarissa. Purple

Darksome. A very dark red._._._._._._._._.

Eleganta. Purple shades

Elizabeth. Bronze

Fairy Queen. Yellow, Pink shading

Joe Fete. White

Klein Domittea. Bright amber

Little David. A fine red_._._.

Little Bessie. Re1_

Madeleine. Red, variegated white. The leading pom pom of this color, long stems and a very fine cut flower variety

Red Indian. Red, fine

Rosalie. Old rose and white, not good

Rothaut. Fine red

Snow Clad. White, free bloomer 


\section{MINIATURE POM POM DAHLIAS}

These new and handsome varieties are imported and found most interesting.

Each. 10.100.

Charlotte, Red Orange

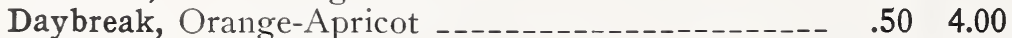

Little Jewel. Pink____- $50 \quad 3.00$

Garden Love. Old Rose

Good Luck. Deep Bright Orange

Rapallo. Carmine tipped. Gold _..- $50 \quad 4.00$

DOUBLE DAHLIAS UNDER COLOR

$\begin{array}{llll}\text { Lavender } & .75 & 6.50 \\ \text { Pink } & & .75 & 6.50 \\ \text { Red } & & .75 & 6.50 \\ \text { Yellow } & & .75 & 6.50 \\ \text { Assorted } & \end{array}$

We have several thousand clumps in red, pink, white and yellow, at $\$ 9.00$ per $100 ; \$ 70.00$ per 1000 .

\section{Rooted Cuttings}

Rooted cuttings have been one of our most successful items among our Dahlia offerings. They not only give the first year the best exhibition flowers but save you many dollars by procuring at low cost the best high priced varieties. We have shipped them to almost every state in the Union and the testimonial letters received have been most gratifying.

\section{HOW TO CARE FOR CUTTINGS WHEN RECEIVED}

Unpack immediately, place in 21/4-inch pots or plant in shallow flats of soil. Shade for several days. Many of our customers report placing cuttings in the open field. Though this method of planting may be successful in a rainy period, one takes chances should hot, dry weather set in. Another good way when danger of frost is past is to plant in cool frames. Cheese cloth makes an excellent shade and also prevents draft from reaching the cuttings.

By this method stock will be ready in ten days and cuttings may be lifted with good soil adhering to roots. Always water well before lifting cuttings. An inexpensive way of shading in open field is to use magazine pages and placing a little soil at both ends. It is surprising how the moisture will remain under this covering.

Orders booked in rotation.

Charge orders not accepted on rooted cuttings.

No cuttings will be sent out earlier than February 1st. Stock shipped only at customer's risk.

Cuttings not returnable. 
DAHLIAS-ROOTED CUTTINGS-Continued

Adda Patterson (D.) Each.

Ambassador (C.)

Arbutus (D.)

.20

$1.50 \quad 10.00$

Avalon (D.)

$2.50 \quad 20.00$

Barbara Wear (D.)

$\begin{array}{lll}.25 & 1.50 & 14.00\end{array}$

Barbara Redfern

(D.)

2.0010 .00

Bashful Giant (D.)

$1.00 \quad 9.00$

$.20 \quad 1.50$

12.00

Bob Pleause (D.)

.20

1.50

14.00

Calizona (D.)

$\begin{array}{ll}.50 & 4.00\end{array}$

Chemars Masterpiece (C).

1.0010 .00

Chemars Eureka

(D.)

3.00

C. De Or. (D.)

$.60 \quad 6.00$

Cigarette

(D.)

.15

1.00

8.00

City of Trenton

(D.)

1.00

Calvin Coolidge

(D.)

.25

2.00

Color Sergeant

(H. C.)

.75

6.00

Eastern Star (D.)

.30

2.50

20.00

Edna Ferber (C.)

1.00

8.00

Eagle Rock Beauty

.75

6.00

Eagle Rock Sunshine

(D.)

.75

Emma Marie (C.)

.20

Eliza Clark Bull

.30

1.50

14.00

Fay Lamphier

(D.)

2.50

$.60 \quad 5.00$

Fort Mammoth (C.)

1.50

Franciscia (D.)

1.00

Grace Jocelyn (D.)

2.00

Harry Mayer

(D.)

Islam Patrol

(D.)

Jane Cowl (D.)

1.0010 .00

Jersey's Beauty

Jersey's Sovereign

(D.)

1.00

Jersey's Beacon (D.)

20.00

Jersey's Masterpiece (C.)

3.00

Kathleen Norris

1.50

Kemp's Violet Wonder (D.)

2.0018 .00

Kentucky (D.)

2.50

King Midas

3.50

Margaret Woodrow Wilson (D.)

1.008 .00

My Maryland (D.)

1.00

Mrs. E. Martin (D.)

Molly Pitcher (D.) 
SHADY LAWN NURSERIES : Hugo KIND : HAMMONTON, N. J.

\section{DAHLIAS-ROOTED CUTTINGS-Continued}

Nancy Sue Lang (D.) Each. 10.100.

N. J. Chamber of Commerce. (D.)

Old Hickory (D.)

Our Country (S.)

$.25 \quad 2.00 \quad 16.00$

Pride of Fort Morgan (D.) _._____ 2.00

Pride of Stratford (D.)

Pop Stewart (D.)

16.00

Post Telegram.

$.40 \quad 3.00$

Regal (D).

2.0018 .00

Rodman Wanameker (D.)

$\begin{array}{lll}.50 & 4.50 & 35.00\end{array}$

Rollo Boy

$\begin{array}{ll}.50 & 4.00\end{array}$

Roman Eagle (D.)

$\begin{array}{ll}.50 & 6.00\end{array}$

Hazel Heitter (D.)

$1.00 \quad 9.00$
.25

Sagamore (D.)

Salbach's White (D.)

$1.00 \quad 8.00$

Shudow's Lavender.

$.25 \quad 2.00$

Stacy Trent (D.)

$1.00 \quad 9.00$

Somerset (D.)

The Lemonade

1.00

Treasure Island (D.)

Trentonian (D.)

$1.00 \quad 9.00$

Watching Sunrise

$1.00 \quad 9.00$

Watchung Sunset

3.00

Waldheim Sunshine

$1.00 \quad 9.00$

World's Best White

(D.)

$\begin{array}{ll}.50 & 4.00\end{array}$

Wizard of $\mathrm{Oz}$ (D.)

$.25 \quad 2.00$

William Hogan (D.)

$1.00 \quad 8.00$

Zues (D.)

$.60 \quad 5.00$

\section{Dahlia Seed}

Per 100.

California Seed. Selected from good varieties.

$\$ 2.00$ 


\section{Gladiolus}

Not less than 25 of a kind; $11 / 2$ inches and up.

Altair (Kunderd). Very early ; pure apricot color

Byron L. Smith. Blue _._._. 3.50

Duchess of York. Deep purple____________ 4.0035 .00

E. J. Shaylor. Considered the best ruffled pink for cut flower use _..... 3.50

Evelyn Kirtland. Flowers a beautiful pink-_-_-_-_-_-_.

Los Angeles.

$3.00 \quad 28.00$

Helen Franklin. White, finely ruffled____________ 3.0018 .00

Maidens Blush (Prim). Delicate salmon pink, slightly flushed light rose, tall growing, very early________- $2.00 \quad 12.00$

Mrs. Frank Pendleton. A beautiful rose pink on a pure white background with deep rich velvety blood red blotches on lower petals_._.

$2.50 \quad 22.00$

Myrtle. _._. 3.50

Nyrah. A fine yellow__________ 3.0028 .00

Odin. Pink. Early. Good forcer. Fine cut flower--_--- 3.0028 .00

Primulinus Hybrids. A new race of remarkable dainty and beautiful gladioli. Perhaps orange and gold colors predominate, but they combine every shade in the rainbow. Usually the flowers are hooded. Somewhat smaller than the ordinary Gladioli and the stems are gracefully curved. Very early -...-_..-_.

Sentinel. A tall and strong rose-pink flaked a darker on the edge and blending to a white throat. Very late-_--

Sheila. Bronze. Good._-_._-_._- 6.00

Vanity. Very tall. Pink. $5 \mathrm{ft}$ spikes.______________ 3.00

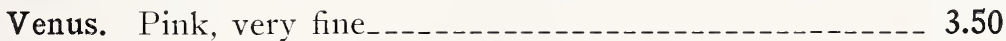

Virginia. The leading early red Gladiolus of today. Ruffled

War. Deep red, large flower

We have from 50,000 upwards of Maiden Blush in second sizes. Planted late, fall flowers may be obtained. Special prices on 10,000 lots. 


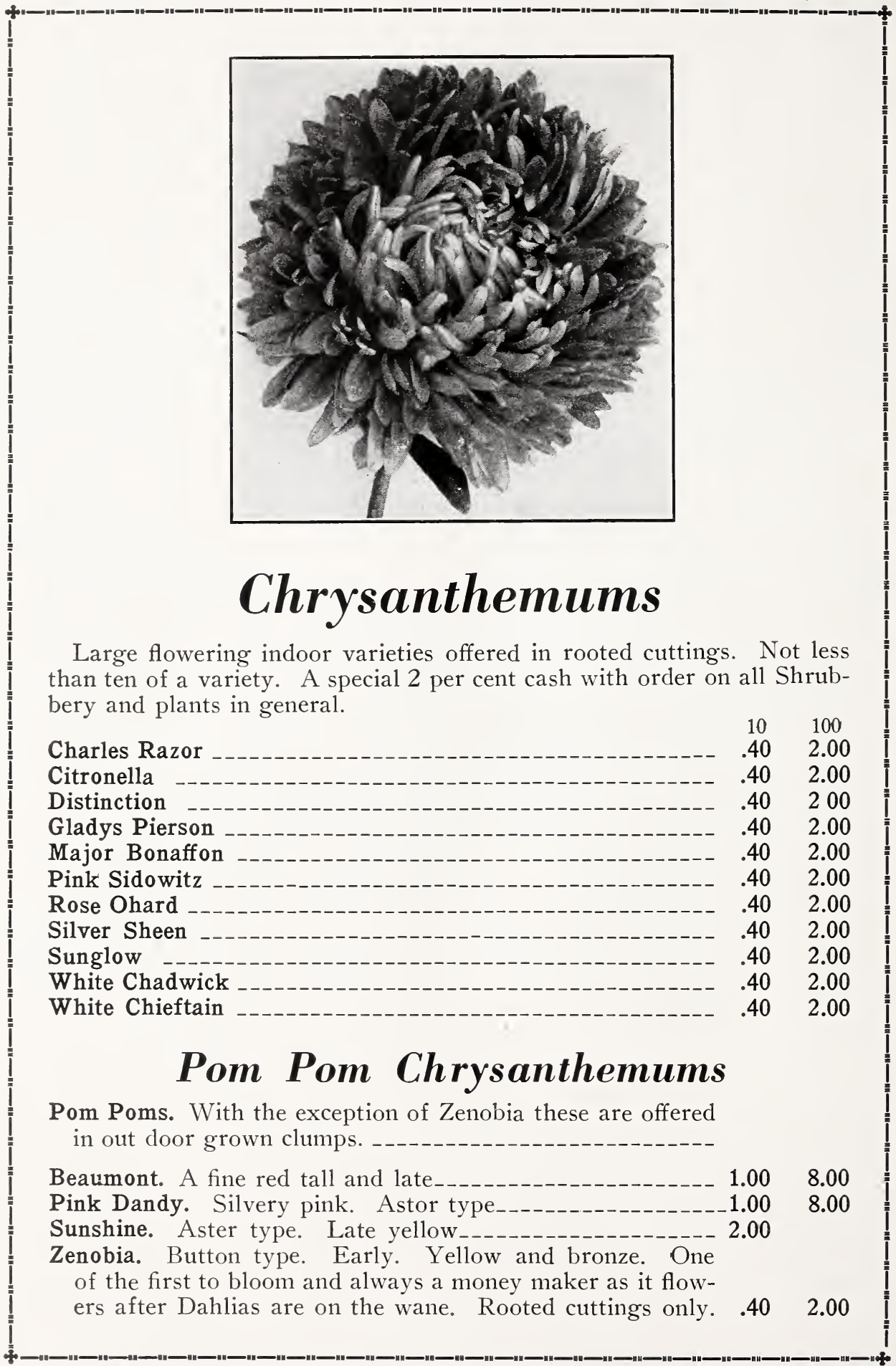

SHADY LAWN NURSERIES : Hugo KIND : HAMMONTON, N. J. 


\section{Hardy Perennials}

(Not less than 3 of a kind)

Achillea

Boule de Niege

Althea or Hibiscus

Red, 3 yr. Double

2 year stock offered

$10 . \quad 100$.

White, 3 yr. Double

Aquilegia

Hybrids

Asclepias

Tuberosa

Artemesia

Silver King

2.00

Aster

Tartarica

1.00

Bleeding Heart (Dielytra Spectabilis) 3.00

Clematis

Paniculata

2.00

Jackmani 3.00

Coreopsis

Lanceolata, 1 yr.

Lanceolata, 2 yr.

-per M, $\$ 18.00$

.50

.75

Daisies

Alaska

Hartje \& Elder (new)

Delphiniums

Belladonna, 2 yr.

Bellamosum, 2 yr.

English Hybrids, 2 yr.

Eupatorium

Coelestinum

Funkia (Hosia)

Albo Marginata (small leaves)_-_-_-_-_-_-_-_-_-_-_ 3.00

Aurea (green yellow stripe)-_-_-_-_-_-__-_-_-_-_-_ 3.00

Corealea (blue flower, large green leaves)

Glauca (bluish leaves) -

Lanceolata (green narrow leaves) --_-_-_-_-_-_-_-_-_- 1.00

Plantizina (subcordato undulata) -_-_-_-_-_-_-_-_-_-_ 2.00

Variegated (Undulata variegata)-_-_-_-_-_-_-_-_-_ 1.00

Sieboldiam (large leaves, very blue) -_-_-_-_-_-_-_-_-_-_10.00

Grasses

Eulalia Zebrina

1.00

Eulalia Japonica

Phalarnius Japonica
8.00

8.00

8.00

8.00

18.00

15.00

10.00

28.00

4.00

6.00

6.00

6.00

8.00

10.00

18.00

8.00

8.00

8.00

18.00

8.00

8.00

8.00

4.00 
HARDY PERENNIALS-Continued

Gypsophila

$10 \quad 100$

Paniculata

1.00

Flora Plena

3.00

Erhlie (Per $1000 \$ 200.00$ )

8.00

Bristol Fairy 3.00

28.00

Hemorcallis

Lemon Lily

1.00

Orange Double 1.00

Orange Single

Iris (German)

Atropurpurea, purple _._.

Black Prince, black _._. 75

Chereax -60

Florentina Alba, white

8.00

8.00

6.00

Honorabilis_-Yellow and Bronze_____________. 65

Queen of May, pink___

4.50

4.50

Sherwin, bright yellow

4.50

Under color, per $1000,38.00$.

Iris (Siberian)

Blue, strong clumps _-60

White - 60

\section{Iris (Dwarf) Pumilo}

These cute little iris attain a height of only four inches.

Fine for rockery or borders. Rare and unique.

Blue

Yellow

Japanese Iris-Named Varieties (All six petal.)

Iso-no-nami _-

Gelska-no-nami _._- 2.00

Enna-no-nami _-___-_- 2.00

Astarte _._. 2.00

Mahogany -

Uchiny _- 2.00

Kolsi-no-cls _._..._.

Hercules _-_-_-_- 2.00

Melpenomi _-___- 2.00

Gold Bond _-_____- 2.00

Mixed _._._. 1.00

Liatris-2 year

Montana (Dwarf) - 2.00

Pycnostachya-Tall and fine, handsome cut flower

Scariosa _-___- 2.00

Spicata, late flowering-________________ 2.00

8.00

Splendens-Known as the bottle brush variety 
Lily of Valley-Convularia

$10 \quad 100$

Pips (per M $\$ 12.00$ )

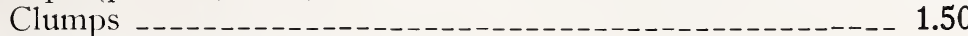

Marshmallow (Hibiscus)

Red, Pink and White

$2.00 \quad 18.00$

Myostis

(Forget-me-110t)

Monarda

Rosea

Pachysandra

Radicans

Peony, 3-5 eye, extra fine.

Rubra Superba

Boule de Niege

Albert Crousse

Assorted

Officinalis Rubra

Phlox (Hardy)

Strong 1-year-old field grown plants.

Antonin Mercie, lilac

Beacon Cherry, red

Mrs. Jenkins, best pure white

Mrs. Lingard

1.25

Phloxes mixed, 1 year old

.75

Rheinlander, salmon pink, red eye

Rynstrom, carmine rose

Thor, deep salmon pink

Physalis Franchetii

Japanese lantern plant

Rudbeckia

Golden Glow

Purpurea

\section{Sedum}

Spectabilis

Tritoma

Pfitzeri

Seedlings, selected 1.00

Viola

Pedata (fine for rockeries)

Odorata (sweet scented)

Lutea (yellow) _-_-_-_-_-_-_-_-_-_-_-_-_-_-_-_._- 3.00

16.00

8.00

Yucca

Filamentosa

Variegated-Fine, large plants for lawn planting 
SHADY LAWN NURSERIES : Hugo KIND : HAMMONTON, N. J.

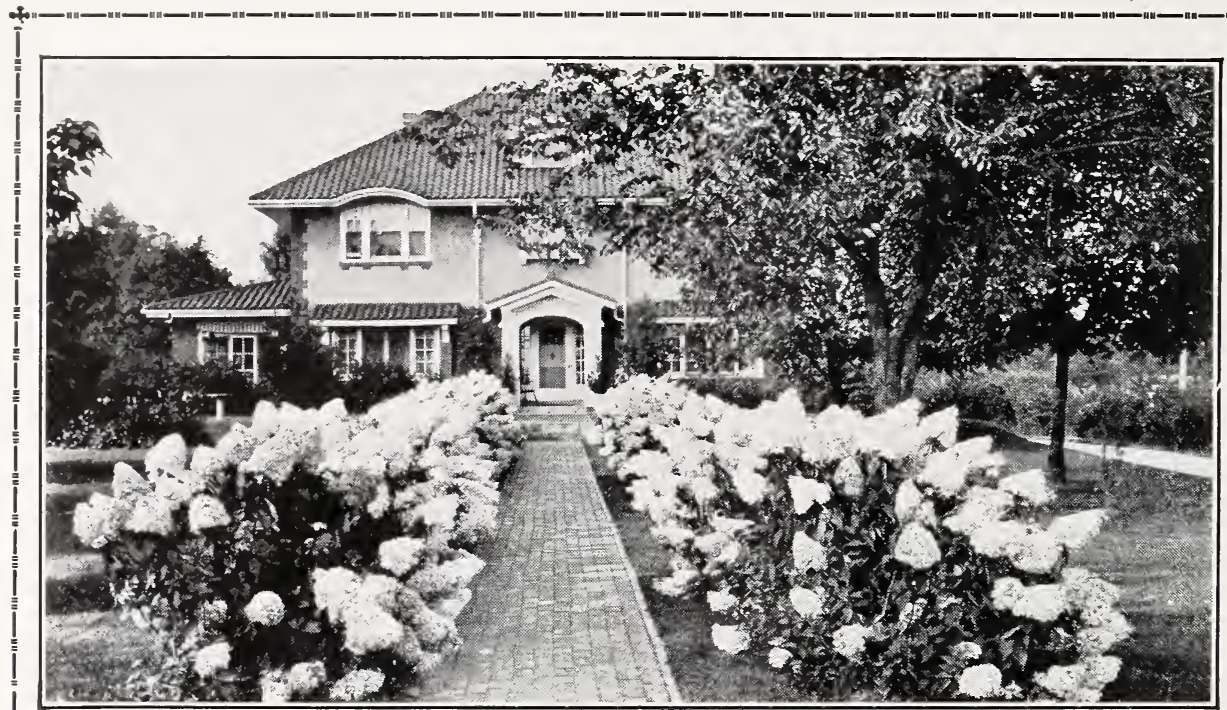

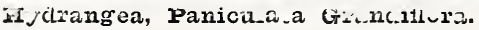

\section{Hardy Shrubbery}

All Stock is Transplanted, Bushy and Well Grown.

Each. 10.100.

1.5012 .00

Althea (Rose of Sharon). 18 to 24 in. asst...-...-Amygdalis

Recl, 4 to $5 \mathrm{ft}$.

Pink, 4 to $5 \mathrm{ft}$.

2.50

Azalea

Amoena, 2 yr.

3.00

Amoena. 3 vr.

6.00

4.00

$1 . \mathrm{CO}$

35.00

Mollis (Seedlings)

Bamboo

Tall hardy 10 to 20 foot in one season. A new novelty and the only stock ever offered. Imported

from Italy ten years or so ago. Large root_-_-_- 2.00

Berberis

Thumbergie, 2 yr., extra bushy_-_-_-_-_-_-_-_---

Blackberry Iceberg. White berries. A wonderful novelty. Edible Boxwood

Sempervirans, 8 to 12 in. bushy, fine

Suffruticosa, 3 to 6 in.

Suffruticosa, rooted cuttings

Butterfly Bush. Fine strong transplanted stock_---

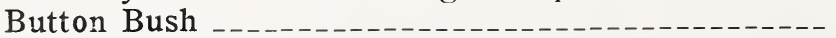

Callicarpa Purpurea 
Caryopteris (Mastacantha)

Each. 10.100.

Clethra Alnifolia (Pepper Bush)

4.00

$1.00 \quad 8.00$

Corchorus or Kerria Japanica fl. Plena

$3.00 \quad 28.00$

Cornus (Dogwood) transplanted

Florida (White)

$3.00 \quad 25.00$

Rubra (Pink)

5.00

Paniculata (Gray Berries)

$3.00 \quad 25.00$

Craetagus (Hawthorne)

Paul's Scarlet. Pink flowers in early spring-

Crepe Myrtle. Pink

Cydonia Japonica, $2 \mathrm{ft}$.

Duetzia, fine and bushy

Rosea Plena, $3 \mathrm{ft}$.

Gracilis, $3 \mathrm{ft}$.

P. Rochester, $3 \mathrm{ft}$.

Exochorda Grandiflora

Pearl Bush

3 to $4 \mathrm{ft}$. at

Forsythia

Fortunei, 2 to $3 \mathrm{ft}$.

Virdissimia

Genista

Terictoria, $3 \mathrm{ft}$.

Halesia

Tetraptera

Holly

Opaca, $2 \mathrm{ft}$.

Honeysuckle (Bush)

Pink, White and Red.

\section{Hydrangea}

Hills of Snow

Paniculata Grandiflora

Otatska (Blue)

Jasmine (Abelia Grandiflora), 2 yr.

Judas Tree (Pink Flowers)

$2 \mathrm{ft}$.

3 to $4 \mathrm{ft}$.

Koelrutia Paniculata

Larche

European. This deciduous evergreen is quite rare.

3 to $4 \mathrm{ft}$

Lespedeza. Bicolor. 3 to $4 \mathrm{ft}$.

\section{Lilac}

Named 10 varieties. Double, single. 3 to $4 \mathrm{ft}$.

Lonicera (Bush Honeysuckle)

Tatarica, 2 to $3 \mathrm{ft}$.

Pink, White, Red 


\section{HARDY SHRUBBERY-Continued}

Maples (Japanese grafted)

Each. 10.100.

Purpurea, 18 in.

3.50

Norway, 4 to $5 \mathrm{ft}$.

.75

Malus (Flowering Crab)

Atrosanguinie, 2 to $3 \mathrm{ft}$

1.50

Mountain Ash

Beautiful trees, transplanted 5 to $6 \mathrm{ft}$.

2.00

Weeping

4.00

Philadelphus (Mock Orange)

Lemoine, 2 to $3 \mathrm{ft}$., fine

Coronarious, 2 to $3 \mathrm{ft}$.

2.00

Photina Villosa

3 yr.

Privet

California, 2 yr.

Mammoth plants, 8 to $12 \mathrm{ft}$.

Variegated, 18 in.

1.00

Robinia Hispida

Roses (Rambler). 3-year transplanted.

Dr. Van Fleet. Pink

Pauls Scarlet Climber

Yellow Rambler

3.50

30.00

White D. Perkins, 2 yr.

3.50

30.00

Pink D. Perkins, 2 yr.

3.50

30.00

Roses (Moss). 3 year.

Pink

White

Sophora (Japanese Pagoda tree) (rare).

Japonica, $4 \mathrm{ft}$.

\section{Spirea}

Anthony Waterer

Billardi Pink

Billardi White

1.00

6.00

Douglasi

3.00

25.00

Thumbergie

Tamarix (African) Large specimen bushes

Vaccinium Corymbosum (Blue Berry)

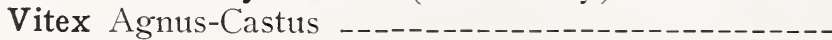

Weigela

Candida, 1 yr.

Eva Rathke, large

$1.50 \quad 12.00$

3.00

Rosea. Extra strong plants

\section{Vines and Creepers}

Ampelopsis Veitchi. 2 yr. 


\section{Fruits}

2 yr. select

GRAPES

10.100.

Agawam

$2.00 \quad 14.00$

Caco

$4.00 \quad 38.00$

Campbell's Early

1.5014 .00

Catawba

1.50

14.00

Champagne Grape. A sterling variety of greatest merit. Color of coppery red. Berries very large. Immense producer. This season in which other varieties did not fruit, this variety stood out bearing an immense crop, very strong grower, fifteen to twenty feet or more a season. Ripens latter part of August. Fruits after Concord.-_---

Concord

$2.00 \quad 18.00$

Diamond

Moore's Early

Niagara

\section{RASPBERRY}

Cuthbert

Cumberland

St. Regis or Ranere

We can furnish St. Regis Raspberry in carload lots. Ask for prices. 100 acres of Certified Mosaic free stock.

\section{CHERRY TREES}

The three Oxhart Cherry (Black, Red White). Strong fine large transplanted trees, each $75 \mathrm{c}$, per ten $\$ 6.00$. One each of the above, $\$ 2.00$.

Compass Cherry Plum. Cross between a Cherry and Plum. Perfectly hardy. Each, \$1.50.

\section{Nut Trees}

Hazel Nut, 4 yr.

\section{Local Landscape Gardener, Florist or Planter:}

It has been our custom to carry in stock a complete line of all Evergreens, Rhododendrons, Large Privet, Trees, Rose Bushes, Flowering Shrubs, Nut Trees, and many other items. As our stock of this line is not sufficiently large enough to list, we therefore offer same only to the local trade. Our Nurseries are threefourths of mile off from the White Horse Pike. A large attractive sign displaying a mammoth pink cactus Dahlia which is erected on the Pike at our road will give you our location. 


\section{Sundries Etc.-Net}

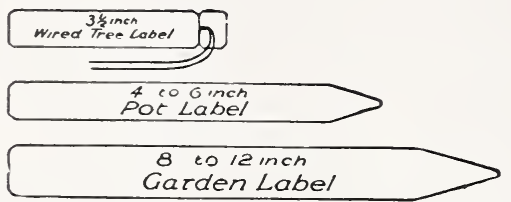

TREE LABELS, ETC.

If wanted by parcel post, add 20c per 1000 . No order under $\$ 1.00$.

100. 1000 .

Iron Wired. Painted 30

1.70

Copper Wired. Plain

2.10

2.10

Copper Wired. Painted _-_-_-_-_-_-_- 402.60

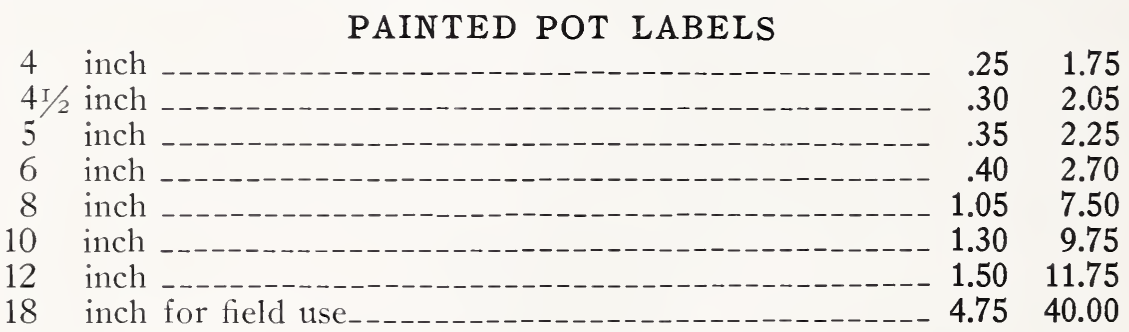

FLATS

We have several hundred flats which we have bought from a factory in another line of business. They vary in size from 3 inches deep to $3 \mathrm{r} / 2$ inches. Width from 14 inches to 16 inches and length from 18 inches to 24 inches. They have never been in the weather and are practically good. as new. Would do fine for spotting your young plants. We use them for Dahlias instead of potting. This assures you of a fine spread root system and dispenses the knotted root when digging.

Per ten 20 cts. each. Per $100, \$ 15.00$.

SEMESAN can be used in either dust or liquid form. It creates a disinfected zone around the seed, bulb or root. Effectively used on gladiolus, aster, dahlia, freesia and hundreds of other flowers. No special skill or equipment required. Try it and save money and blooms.

Not shipped Parcel Post.

\section{PRICES}

2 oz. $\$ \quad .50$

$5 \mathrm{lbs}$.

8 oz.

$1 \mathrm{lb}$.

$50 \mathrm{lbs}$. 122.50

100 lbs.

240.00 


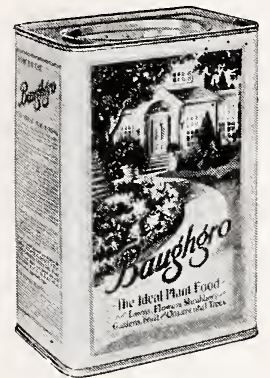

House of Baugh, founded in 1817.

A specially prepared Plant Growth Activator for

\section{DAHLIAS}

FLOWERS, SHRUBBERY, LAWNS AND GARDEN, FRUIT AND ORNAMENTAL TREES

A Complete Plant Food Promoting Wonderful Growth and Luxuriant Blooms

Made by Baugh and Sons Company The Oldest American rertilizer Mranufacturers.

Ammonia

\section{Guaranteed Minimum Analysis}

Available Phosphoric Acid

Potash (water Soluble)

Net Weight

5 lb. Can

P, ice Each Wh lesal.

25 1b. Bag

50 lb. Bag

100 lb. Bag

BAUGH'S PURE RAW BONE MEAL

for Lawns, Flowers, Gardens, Shrubs and Trees

Guaranteed Minimum Analysis

Total Phosphoric Acid

Ammonia

Net Weight

5 lb. Can

Price Each Wh lecal

25 lb. Bag

50 lb. Bag

BAUGH'S SHEEP MANURE

Net Weight for Lawns, Flowers and Gardens

50 lb. Bag 


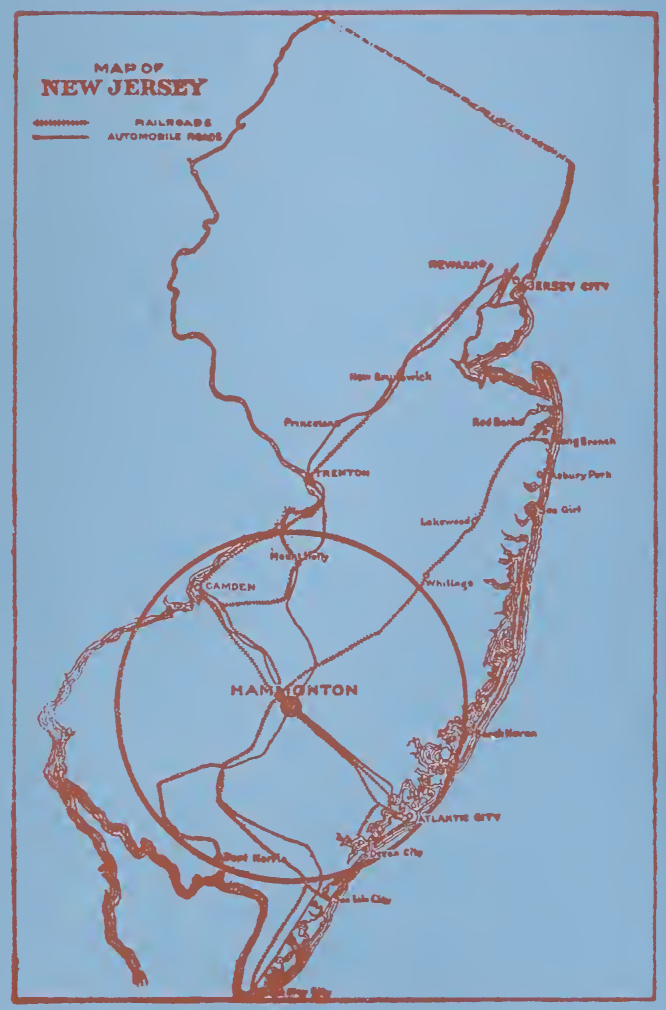

THE WILLIAM BYRD PRESS. INC.
HORTICULTURAL PRINTERS. RICHMOND VA 
